\title{
Firm Performance when Ownership is very Concentrated: Evidence from a Semiparametric Panel
}

July 25, 2015

\begin{abstract}
We consider the effect on performance of very large controlling shareholders, who are mostly organized in voting blocks and business groups, in a sample of Belgian listed firms from 1991 to 2006. Since the shape of the relation between ownership and firm value is a controversial issue in corporate finance, we use semiparametric local-linear kernel-based panel models. These models allow us not to impose a priori functional restrictions on the relation between ownership and performance. Our semiparametric analysis shows that the effect on performance varies depending on the size of ownership stakes and that there are departures from linearity, especially in family firms. Our results suggest that this non-linearity in family firms is related to whether or not the CEO is a family member.
\end{abstract}

Keywords: Semiparametric panel, Ownership concentration, Large shareholders, Firm performance, Family firms.

JEL Classification: C14; C23; G32 


\section{Introduction}

Most of the literature that examines the impact of ownership structure on firm performance investigates the issue of managerial ownership in corporations with diffuse ownership. Giving managers a stake in the firm in the form of ownership is generally thought to align the interests of managers and dispersed shareholders, and to resolve the conflict of interest between them (see e.g. Berle and Means 1932, Jensen and Meckling 1976). A related issue is the effect of large shareholders. On one hand, they have the incentives to oversee the managers in order to maximize firm value and help overcome the agency problem (see Shleifer and Vishny 1986, Shleifer and Vishny 1997). On the other hand, there might also be costs associated with the presence of large shareholders. For instance, Stulz (1988) provides a theoretical framework, in which the relation between managerial ownership and firm value is concave. He shows that, beyond a certain point, managerial ownership has a negative effect on firm value, because managers have the ability to entrench themselves and block value-enhancing takeovers.

While there is no agreement on the direction of the relation between ownership and performance in the theoretical literature, there is also a controversy in empirical studies regarding its shape. For instance, using a piecewise linear specification, Morck, Shleifer, and Vishny (1988) and Cho (1998) find a non-monotonic relation between managerial ownership and performance, while Hermalin and Weisbach (1991) report an inverse W-shaped relation, Cui and Mak (2002) find a W-shaped relation, McConnell and Servaes (1990) use a quadratic specification, Short and Keasey (1999) use a cubic specification, and Davies, Hillier, and McColgan (2005) a quintic form 1 Demsetz and Villalonga (2001) summarize the controversy about the shape of the ownership performance relation in a graph, which we reproduce in Figure 1.

In this paper we analyze the impact of ownership concentration on performance in a panel of Belgian listed firms, observed from 1991 to 2006 using semiparametric kernel-based local-linear pooled, random and fixed effects models, which can accommodate any type of functional form. We find that the effect of large shareholder ownership on firm perfor-

\footnotetext{
${ }^{1}$ See also Chen, Ho, Lee, and Shrestha (2004), who discuss the use of non-linear specifications in corporate finance studies.
} 
mance is non-monotonic and that there are non-linearities captured by the nonparametric estimation. Our paper makes a number of contributions.

First, we use an innovative econometric technique, which has been developed recently and is not part of the standard toolbox in financial econometrics or empirical finance. We show how kernel-based local-linear semiparametric pooled and random (see e.g. Wang, Carroll, and Lin 2005), as well as fixed effects estimation (see Henderson, Carroll, and Li 2008) can be performed in a unified framework. A semiparametric method allows us not to impose any a priori functional restrictions on the effect of ownership on firm performance, and including fixed effects allows us to deal with potential endogeneity of ownership concentration, our main variable of interest. Using nonparametric techniques is particulary relevant in this literature, since the shape of the relation between ownership and performance is so controversial. Indeed, almost every study seems to find a different shape, or impose a different functional form on the relation between ownership and performance. To the best of our knowledge the only two papers that use a semiparametric approach to explore ownership and performance are Gorton and Schmid (2000) and Florackis, Kostakis, and Ozkan (2009). Gorton and Schmid (2000) fail to find evidence of non-linearities in two separate cross-sections of German firms in 1975 and 1986, but their results are based on fairly small sample sizes. More recently, Florackis, Kostakis, and Ozkan (2009) use a semiparametric pooled estimation for a sample of UK firms and they find a non-monotonic association between executive ownership and performance with an alignment effect up to 15 percent ownership. Beyond that level they identify several possible turning points, but the effect is no longer statistically significant. While in panel data it is common practice to control for firm heterogeneity by including firm fixed effects, these papers fail to address this issue. It is well-known in empirical research that results with or without fixed effects (either pooled or with random effects) can be radically different. It is not rare to see sign reversals or significant results based on pooled regressions that become insignificant, once fixed effects are included. The trouble is that whenever results differ across estimation methodology, this means that parameters estimated from pooled or random effect are inconsistent, which means that the coefficients are subject to positive or negative biases of arbitrary magnitude. Including a fixed effect allows to control for potentially endogenous 
unobserved time-invariant cross-sectional heterogeneity, a problem that typically plagues economic and financial panel data.

Our second contribution is to provide evidence on very high levels of ownership concentration not considered before in the literature. We carefully construct a unique and detailed database of Belgian listed firms and the composition of their shareholdings for a period of sixteen years, from 1991 to 2006. The first quartile of share ownership of the leading shareholder is about 40 percent of voting rights, and the average shareholder holds about 54 percent. This very high concentration is rather uncommon and it is a unique Belgian feature. While Belgium is an example of the continental European tradition of ownership concentration, there are specific legal mechanisms, such as the recognition of voting blocks and the prevalence of business groups, that exacerbate this concentration. Voting blocks are formal agreements amongst shareholders that are explicitly allowed by law. In this regard, Belgium offers a unique laboratory to examine the impact of powerful controlling shareholders, grouped in voting coalitions, on firm performance. In addition to the high level of ownership concentration, the Belgian corporate system is characterized by a fairly small and illiquid stock market with few listed firms, and the predominance of holding companies with a close link to families 2

Our third contribution is that we depart from the mainstream literature on ownership and performance, which is based on U.S. firms and considers the share ownership of insiders who are usually managers and members of the board. These papers aim to test the hypothesis of Berle and Means (1932) on the separation of ownership and control and investigate whether managerial ownership provides an incentive for managers to maximize firm value and consequently reduce agency problems between them and dispersed shareholders. Instead, we focus on ownership concentration, because even though managerial ownership is present, the Belgian context is one of high levels of ownership concentration in the hands of a very small number of shareholders, who are mostly voting blocks and/or business groups. Thus the agency problem is not between managers and shareholders, but between large

\footnotetext{
${ }^{2}$ Chen, Firth, and $\mathrm{Xu}(2009)$ document levels of ownership concentration in China that are comparable to the ones in Belgium. However, in $75 \%$ of the firms in China, the largest shareholder is the State or one of its affiliates, and thus one can expect the motivations and objectives of shareholders as well as potential conflicts of interest to differ greatly between China and Belgium, especially given the stark differences in the economic tradition and corporate systems of the two countries.
} 
controlling shareholders and the smaller ones. Our paper differs also from most studies on ownership concentration, which are usually interested in the divergence between ownership and control and the deviation from one-share one-vote through devices such as multiple class shares, pyramids, and/or cross-shareholdings (see for instance La Porta, Lopez-de Silanes, and Shleifer 1999, Claessens, Djankov, and Lang 2000, Faccio and Lang 2002, Bennedsen and Meisner Nielsen 2010). Our paper is related to Cronqvist and Fahlenbrach (2008), who investigate the role of large shareholders on corporate policy choices and performance in a sample of U.S. firms with blockholders. However, the size of blocks in their sample, which averages 9.6 percent, is much smaller than the average 54 percent in our Belgian listed firms.

Fourth, we contribute to the literature on the performance of family firms. In terms of the prevalence of family firms, Belgium is in line with the continental European tradition. Many studies analyze family firms for different countries and most of the results seem to support the view that family firms perform better than the others (see for instance, Anderson and Reeb (2003) and Villalonga and Amit (2006) for two different samples of U.S. firms, Sraer and Thesmar (2007) for a sample of French firms, and Maury (2006) for 13 Western European countries). The main argument in favor of the superior performance of family firms is that families are stable long-term investors who are there for several generations (see e.g. James 1999, Anderson and Reeb 2003). However, having a family as a controlling shareholder can also lead to poor performance if the family chooses to take advantage of its position, exchange profits for private benefits, and forgo profitable projects, see for instance Demsetz (1983). A number of studies report this adverse effect of ownership on performance in family firms, see for instance Bennedsen, Meisner Nielsen, Perez-Gonzalez, and Wolfenzon (2007) for Danish firms, Morck, Strangeland, and Yeung (2000) for a sample of Canadian firms, and De Angelo and De Angelo (2000) for a case study of the Times Mirror company.

Finally, we also explore the effect of ownership on performance for firms related to coordination centers and firms without such a link. Coordination centers were created in Belgium in 1982 to attract multinationals to relocate their financial operations in Belgium and to favor employment. These centers provide a large range of financial services to the 
sole benefit of their group members on a roughly free tax basis. They were prohibited in 2008 (some continue to operate until 31 December 2010 under certain conditions), but were operating during our sample period and constitute a main characteristic of the Belgian corporate system.

The rest of the paper is organized as follows. Section 2 describes our data, and Section

3 is dedicated to the description of the large controlling shareholders. In Section 4 we present the estimation framework, Section 5 discusses the results, Section 6 performs some robustness checks, and Section 7 concludes.

\section{Data}

In this section, we discuss our sample selection, the construction of our ownership data from a number of different sources, a discussion of our identification of family firms, as well as the sources we rely on for the other variables.

\subsection{Sample selection}

Our sample consists of all Belgian listed firms except those in the financial sector, such as banks, insurance companies, common investment funds, companies active in or related to financial intermediation, as well as real estate firms. We also exclude some companies in coal mining and steel production that were involved in a long liquidation process but were still listed and had incomplete data. We limit ourselves to firms with available balance sheet data and a declaration of ownership to the Banking Commission, therefore, out of an initial total sample of 243 firms we end up with an unbalanced panel of 194 firms with 1676 firm year observations between 1991 and 2006.

\subsection{Ownership data}

In Belgium, the disclosure law of 1989 makes notifications to the Banking Commission of share ownership in listed firms mandatory for all shareholdings of at least 5 percent of voting rights. This threshold could be as low as 3 percent if the firm writes this into its statutes, see Appendix A for more details. Hence, ownership information is public, and it is featured in 
a number of databases: (1) BDPart at the Documentation and Statistics Department of the Brussels Stock Exchange records the current ownership of listed firms, but unfortunately it does not keep historical data; (2) the "Centrale des Bilans" database at the National Bank of Belgium (NBB) provides ownership data, but it only keeps track of Belgian shareholders; (3) "Belfirst" from Bureau Van Dijk starts recording ownership positions of listed firms in 1997, but this data is not of sufficient quality and it requires what amounts to an almost manual cleanup 3 Due to these limitations with available databases, in order to carry out this study, we had to construct our own ownership data manually. We start in 1991, since there was a grace period of two years for some firms after the adoption of the law in 1989, but by the end of 1991 all firms were required to report their shareholdings. Our sample ends in 2006, since after 2006, the Belgian law regarding ownership notifications thresholds was modified. To collect ownership data, we rely on several sources: (1) annual reports of listed firms; (2) notifications available in the Documentation and Statistics Department of the Brussels Stock Exchange; and (3) yearly publications of the shareholdings of Belgian listed firms from the "Research and Strategy Department Equity Research" at ING bank (previously BBL). We proceed as follows. First, we use the firms' annual reports to collect ownership, as this provides us directly with year-end ownership stakes. Second, in case of missing annual reports, we resort to the hardcopy notifications from the Documentation and Statistics Department of the Brussels Stock Exchange, which record every change in ownership composition. This is more detailed, but less practical for the purpose of constructing year-end positions.

\subsection{Family firms}

In addition to the whole sample, we estimate separate models for family and non-family firms. Introducing such a distinction makes results potentially sensitive to the criteria used to recognize family firms. In this regard, thanks to the Belgian disclosure law, we have available the declarations of control of shareholders of listed firms to the Banking Commission, which clearly state whether a shareholder is a family group. The declarations even

\footnotetext{
${ }^{3}$ For instance, for some firm year observations, shareholders appear twice with different shareholdings. In other instances shareholders disappear for a year and then reappear, and sometimes, after verification, it turned out that the data had not been updated.
} 
identify family firms when they are controlled indirectly via a pyramid-scheme. Furthermore, many Belgian firms have their origins in the 19th century, and the matters of family succession and wealth of Belgian dynasties are widely documented in the Belgian press, which leaves us with another source to compare the results of our classification to (see e.g. Coenjaerts, Buron, Charlot, and Halloy 2007). Thus our identification of family firms is close to the one of Sraer and Thesmar (2007), who define a family-firm as one where the founder or the heir is in control. However, our classification differs from Faccio and Lang (2002) (F\&L thereafter) who consider as family firm any firm whose controlling shareholder is either a family (including an individual) or an unlisted company for a sample of 13 Western European countries (including Belgium). More recently Franks, Mayer, Volpin, and Wagner (2012) trace the ultimate ownership of private as well as listed companies through ownership chains involving both listed and private companies in France, Germany, Italy and the UK. They find several misclassifications of family firms by F\&L for these countries. A comparison of our family firm data, for Belgium, with the one of F\&L reveals that for 8 firms that are family-firms according to F\&L, we find no such link (false positives), while we find a link to a family for 7 firms that are not family-firms according to F\&L.

\subsection{Other data}

Following the literature on ownership and performance (see e.g. Morck, Shleifer, and Vishny 1988, McConnell and Servaes 1990, Short and Keasey 1999, Davies, Hillier, and McColgan 2005), we control for firm size, proxied by log of total assets, leverage, which we measure as short and long term debt, investment, proxied by capital expenditures, R\&D as a proxy for investment opportunities, and investment in financial fixed assets, which is an important part of Belgian firms' investments. All these variables are weighted by total assets. Our dependent variable is firm performance, which we measure as market-to-book ratio (as a proxy for Tobin's q). All the accounting data we need to construct these variables come from two sources. For the 1991-1996 period we rely on the NBB's "Centrale des Bilans" database 4 and for the 1997-2006 period, we use the "Belfirst" database of Bureau Van

\footnotetext{
${ }^{4}$ We use two CD-ROMs with the data from NBB: the first one, edited in 1995, contains annual accounts for 1991, 1992, and 1993; the second one, edited in 1998, contains annual accounts for 1994, 1995, and 1996.
} 
Dijk. In order to merge data from all these different source, we identify firms by their VAT code 6 Finally, in order to compute market-to-book value, we collect year-end market capitalization of listed firms from the Brussels Stock Exchange.

Table 1 defines our variables, while Table 2 shows descriptive statistics for the different variables we use in our analysis. On average, market-to-book value is about 1.15 for the whole sample. Family firms have the highest average market-to-book value with 1.41 against 1.02 for non-family firms, with a statistically significant difference, while it is 1.12 and 1.16 for firms related to coordination centers and those without such a link, but the difference is not significant. There is no statistically significant difference between family, and nonfamily firms in terms of size, debts, investment in financial fixed assets, capital expenditures, or R\&D. Firms affiliated to a coordination center are significantly larger in terms of size, short and long term debt, investment in financial fixed assets, than those without such a link, while in terms of capital expenditures there is no statistically significant difference.

\section{$3 \quad$ Large controlling shareholders}

In the literature there are two opposing views on the outcome of ownership concentration on firm value. One line of reasoning is that ownership concentration is a way to provide shareholders with an incentive to monitor managers, which will result in a positive association between ownership concentration and firm value. Shleifer and Vishny (1986) provide a theoretical justification for this argument, which they confirm in their survey of corporate governance in 1997, where they state that large shareholders have the ability to "address the agency problem in that they have both a general interest in profit maximization, and enough control over the assets of the firm to have their interest respected" (Shleifer and Vishny (1997), p.754). This positive effect of ownership concentration on firm value is confirmed for instance in Gorton and Schmid (2000) for a sample of German firms, in Xu and Wang (1999) for Chinese firms or in Sarkar and Sarkar (2000) for a sample of Indian firms.

However, there is an alternative theory, which holds that ownership concentration might

\footnotetext{
${ }^{5}$ We use the year end CD-ROMs for every year from 1997 to 2006.

${ }^{6}$ In order to identify listed firms from the Brussels Stock Exchange, we look up their names in the "Mémento des Valeurs" to obtain their VAT codes, which allows us to uniquely identify them on NBB or "Belfirst" sources. This avoids any possible confusion between firms with similar names.
} 
be a way of diverting resources. This view is also expressed in Shleifer and Vishny (1997), p.759: "As ownership gets beyond a certain point, large owners gain nearly full control of the company and are wealthy enough to prefer to use firms to generate private benefits of control that are not shared by minority shareholders." Similarly, Claessens, Djankov, Fan, and Lang (2002) argue that the valuation discount prompted by large entrenched owners in East Asian countries is not due to actions related to blocking value-enhancing takeovers, but is related instead to extraction of private benefits and direct expropriation through transfer of financial wealth to affiliated firms. Johnson, La Porta, Lopez-De-Silanes, and Shleifer (2000) refer to the transfer of resources out of a company to its controlling shareholders as "tunneling". They point out that this expropriation can take different forms, such as the transfer by the controlling shareholder of resources from the firm to his own benefit through self-dealing transactions; transfer pricing advantageous to the controlling shareholder; excessive executive compensation; loan guarantees to the controlling shareholder; expropriation of corporate opportunities, and so on. Denis and McConnell (2003) argue that the evidence from around the world indicates that the relation between ownership structure and firm performance varies both by country and by block holder identity but most often ownership concentration has a positive effect on firm value.

Usually a distinction is made between Anglo-Saxon corporations with diffused ownership, and continental European ones where ownership is concentrated in the hands of a small number of shareholders (see e.g. La Porta, Lopez-de Silanes, and Shleifer 1999, La Porta, Lopez-de Silanes, Shleifer, and Vishny 2000, Becht and Mayer 2001, Franks and Mayer 1995). While the level of concentration is much lower than in continental Europe, even in the U.S. and the U.K. large share stakes and dominant shareholders are not that uncommon (see e.g. Holderness and Sheehan 1988, Zwiebel 1995, Leech 2002, Demsetz 1983, Shleifer and Vishny 1986, Morck, Shleifer, and Vishny 1988, Holderness 2003, Cronqvist and Fahlenbrach 2008, Holderness 2009). The literature generally considers that ownership is concentrated if the largest shareholder holds more than 10 percent of voting rights. Sometimes that threshold is set at 20 percent (see for instance studies such as La Porta, Lopez-de Silanes, and Shleifer 1999, Claessens, Djankov, and Lang 2000, Faccio and Lang 2002). In this paper we are far above these figures, since the average shareholder holds about 54 
percent of voting rights.

In Belgian listed firms, there exist three types of shareholders: (1) individual shareholders (physical or moral persons); (2) collections of shareholders gathered in a business group or (3) collections of shareholders gathered in a voting block. Individual shareholders, either moral or physical persons, hold direct stakes in the firm. Business group blocks are the stakes of companies that are part of a business group, which consists of a set of legally distinct entities under the control of a large corporate owner. While business groups are subject to consolidation rules under Belgian law, the legal independence of their affiliates preserves their limited liability in case of bankruptcy. A voting block is a coalition of shareholders, who officially (and publicly) declare that they act in concert. This is a formal agreement, allowed by Belgian law, between a number of shareholders, either individuals and/or business groups. These agreements are typically entered into with the objective of gaining greater control. The share ownership of the largest shareholders is already very high without taking into account voting blocks, but voting blocks make the concentration of ownership even higher.

Panel A of Table 3 shows the nature and size of the main groups of shareholder by twodigit NACE code. In the whole sample, of all shareholders that are part of a voting block, in terms of shareholder year observations, more than 48.6 percent are financial intermediaries, and this number increases to more than half, if one adds the 2.3 percent of shareholders whose activity is auxiliary to financial intermediation. Another large group is physical persons, who make up 14.8 percent of all shareholder year observations. Institutional investors, such as insurance and pension funds make up less than 4 percent of all shareholder year observations. Real estate companies also represent a significant group of shareholders, with 3.93 percent of the total. The rest of the shareholders are companies in various fields of services or industrial sectors. On average financial intermediaries have fairly large stakes (17 percent). The patterns are very similar for shareholders that are not part of any voting blocks. In family firms there is a slightly stronger prevalence of shareholders that are physical persons and of real estate companies and fewer financial intermediaries, relative to non-family firms (still in terms of shareholder year observations). Note that the companies that are shareholders of family firms are in turn controlled by the family. For instance, 
in many cases, financial intermediaries that are shareholders of family firms correspond to holding companies, controlled by the family.

We define a number of ownership variables, that reflect the different possible ways of aggregating shareholdings. We start out from the variable Single shareholder, which considers all declared shareholders in a firm individually. This means that there can be more than one in each firm at each point in time, as long as their holdings are above the threshold that triggers a declaration to the Banking Commission. Next, we build the variable Largest shareholder without voting blocks, which takes the largest of all single shareholders for each firm and each year. Finally, to build the variable Largest shareholder (with voting blocks), we take the share ownership of the largest shareholder, after aggregating up the shares of all shareholders in the same business group and/or voting block and treating them as if they were one shareholder. We refer to Table 1 for a definition of the variables.

We assess ownership concentration in two ways: first we analyze the percentage of share ownership, and next we look at the number of declared shareholders in a given firm. In terms of the number of shareholders, Figure 2 shows that there are very few different shareholders in the same firm. For instance, in about 15 percent of firm-year observations, there is only one single declared shareholder and in about 62 percent there are between one and four shareholders in the same firm. There is only one percent of firm-year observations with more than 18 shareholders and a maximum of 26 . While the number of shareholders is small to begin with, these shareholders generally join together and form voting blocks. When we consider voting blocks, the number of shareholders decreases even more. Column (1) of Table 3, Panel B shows that in almost 30 percent of firm-year observations there exists only one voting block, in 1.97 percent there are two, and in 0.36 there are three. Column (2) of Table 3, Panel B shows that there is a single business group in almost 37 percent of firm-year observations, while two business groups locate in the same firm in only 9 percent of observations. Finally, it is only in less than 1 percent of observations, that there are as many as 4 or 5 business groups. These business groups can also join together and form voting blocks. According to Column (3) of Table 3, Panel B, in almost 8 percent of firm-year observations one business group is a member of a voting block and in almost 7 percent there are between 2 and 4 business groups that form voting blocks. 
There are also interesting patterns in terms of percentage share ownership. Table 2 shows that the distribution of all shareholders taken individually without making any distinction between them has an average of about 14 percent. However, this average jumps to 43 percent, when we consider only the largest shareholder in the firm but without taking into account voting blocks or business groups formations. These figures are even higher when we further take into account voting blocks, and the average increases to around 54 percent.

The distribution of the large controlling shareholders confirms that shareholders form voting blocks in order to gain more control. This is obvious if we compare Column (a) of Figure 3, where we take into account all individual share holdings in the firm, to Columns (b), in which we consider only the first largest shareholders for the whole sample in the first row, as well as for the subsamples of family, non-family, coordination center, and noncoordination center firms in subsequent rows. The histograms in Column (c) of Figure 3 show the distribution of large controlling shareholders when we further take into account business groups and voting blocks. There are concave bumps in the distribution of share ownership, which correspond to thresholds that are meaningful in terms of control. The histograms in Column (c) shows significant concave bumps in the 50-55 percent range, which correspond to absolute majority. There are also bumps in the 25-30 percent range, which could be due to the Belgian legislation on tax reduction on dividends. Indeed, according to Belgian law when a shareholder reaches 25 percent of voting rights she/he benefits from an exemption of taxes on dividends. This applies exclusively to shareholders that are companies, and not to physical persons. The last bumps are at 75 percent, which is the threshold required by Belgian law to modify the statutes of the firm. A comparison of the histograms in Column (b) with those of Column (c) reveals that while the distribution of share ownership is different, bumps are found at the same thresholds, but with different magnitudes. The histograms also reveal that there are very few observation below 10 or 15 percent and above 85 or 90 percent, depending on the sample we consider, and one should keep this in mind when interpreting the nonparametric results below. 


\section{Estimation framework}

We estimate a nonparametric panel, because this gives us the flexibility not to impose any a priori functional form on the variables of interest, while simple econometric models assume functional forms that are either linear, piecewise linear with arbitrary cut-offs, or sometimes quadratic or of even higher order. While economic theory often predicts the sign of the relation between variables, it rarely provides predictions about its shape. The nonparametric methodology allows us to be agnostic about the functional form of the relation between the variables of interest. This is of particular relevance for ownership and performance, where there is little agreement about the functional form (see e.g. Demsetz and Villalonga 2001).

While nonparametric techniques have a long history, nonparametric panel methods have been developed more recently, and they have spurred recent interest in the econometric literature. For instance, using semiparametric fixed effects estimation, Kan and Lee (2012) study the effect of weight on wages, controlling for height, Zhou and Li (2011) analyze the effect of development on inequality, while Chen and Dong (2012) use such a model in the context of trade. Yet, the idea of carrying out nonparametric and semiparametric estimation in the context of panel is not new. Early references include Ullah and Roy (1998), who discuss various estimators. In the case of the random effect, Henderson and Ullah (2005) put forward feasible versions of some of the nonparametric random effects estimators considered in Ullah and Roy (1998), but they do not consider the semiparametric case. In this paper, we use a local linear kernel-based approach.

We run our parametric and semiparametric estimation not only in pooled panel, which could deliver biased estimates, but also with random and fixed effects. The random effect assumption allows to deal with firm heterogeneity, while the fixed effects model allows us to deal with endogeneity by controlling for time-invariant cross-sectional heterogeneity, that could be correlated with the regressors.

For the sake of comparison, we first use parametric panel data models of the impact of ownership concentration on firm performance and other control variables. The basic pooled 
OLS model is:

$$
Y_{i t}=\mu_{0}+Z_{i t} \theta+X_{i t} \beta+\epsilon_{i t}, \quad t=1, \ldots, T_{i}, \text { and } i=1, \ldots, n,
$$

where $Y_{i t}$ is performance, $Z_{i t}$ is shareholdings of the largest controlling shareholders, $X_{i t}$ includes other control variables, such as firm size, short and long term debt, investment in financial fixed assets, capital expenditures, $R \& D$, and a set of time dummies, $\mu_{0}$ is the intercept, $\theta$ and $\beta$ are coefficients, $\epsilon_{i t}$ is an error term, and we have an unbalanced panel with $T_{i}$ time series observations for firm $i$.

We also estimate both fixed and random effects models, which correspond to different assumptions on the error term, $\epsilon_{i t}=\mu_{i}+\varepsilon_{i t}$, where $\varepsilon_{i t}$ is assumed to be homoscedastic and uncorrelated over time. Under the random effects assumption, $\mu_{i}$ is a time invariant firm-specific zero mean homoscedastic random term, which is independent of $\varepsilon_{i t}$. In the fixed effect case, the model changes to:

$$
Y_{i t}=\mu_{i}+Z_{i t} \theta+X_{i t} \beta+\varepsilon_{i t}
$$

where $\mu_{0}$ is omitted, as it is subsumed by the non-stochastic firm-specific intercepts $\mu_{i}$.

We are interested in the following partially linear panel specification:

$$
Y_{i t}=\theta\left(Z_{i t}\right)+X_{i t} \beta+\mu_{i}+\epsilon_{i t} .
$$

where $\theta(z)$ is now a potentially non-linear mean function, and its first derivative, $\frac{\partial \theta(z)}{\partial z}$ can be interpreted like a parameter: if $\theta(z)$ is linear, $\frac{\partial \theta(z)}{\partial z}$ is constant, and we are back in the parametric case. Our specification is a semiparametric one, where the effect of ownership $Z_{i t}$ is nonparametric, while control variables $X_{i t}$ enter linearly. This avoids the well-known curse of dimensionality, and focuses attention on the object of interest, which is the potentially non-linear relation between ownership and performance. Like in the linear case, we entertain the semiparametric model (3) under the same three assumptions about $\epsilon_{i t}=\mu_{i}+\varepsilon_{i t}$ : pooled with $\mu_{i}=0$, random effects with $\mu_{i}$ random and independent and fixed, where $\mu_{i}$ is a firm-specific constant. For the pooled and random effects estimation, we use the estimation procedure proposed by Wang, Carroll, and Lin (2005) for the efficient 
estimation of a semiparametric regression with cluster level random effects. For the fixed effects estimation we rely on Henderson, Carroll, and Li (2008). For more details about the estimation procedure, we refer to Appendix B.

\section{Results}

Table 4 contains results for the full sample, and then separately for family and non-family firms, while Table 5 shows results when we split the sample between firms related to a coordination center and firms without such a link. In each case, we estimate both parametric and semiparametric versions of the pooled, fixed and random effects models. Panel A of the tables shows the parametric estimation, and Panel B shows the linear part of the semiparametric models.

We first analyze parametric results. In most cases a Hausman test favors the fixed effects model, which points to the inconsistency of the random effects estimator 75 We focus on results with fixed effects, as they are consistent under any assumption on the firmspecific effect. The parametric results show a positive effect of ownership concentration on firm performance in the full sample. This effect is positive and strongly significant for non-family firms while it is negative but insignificant for family firms. This suggests that there is an alignment effect for firms not related to families, while there is apparently no effect of ownership concentration on performance for family firms.

While the effect of ownership of the largest shareholder on firm performance is positive and of similar magnitude for firms with and without a link to a coordination center, this effect is only marginally significant for firms affiliated to a coordination center. Thus it seems that the overall positive effect is driven mainly by non-family firms, and firms not affiliated to a coordination center.

Next we examine the semiparametric results, which deliver a more nuanced picture with important departures from linearity, especially for family firms. Before starting to interpret the nonparametric results, we reiterate that in many cases, as can be seen from Figure 3 , there are only very few observations at both extremes of the ownership distribution, and

\footnotetext{
${ }^{7}$ The exception is the case of coordination centers, where ownership concentration is only marginally significant (at 10\%).
} 
thus results below 10 or 15 and above 85 or 90 percent of ownership are likely to be driven by a very small number of points, and one should therefore abstain from reading too much into the shape of the curve in those areas (see also Florackis, Kostakis, and Ozkan 2009). Figure 4 shows the nonparametric effect of ownership on performance for the whole sample for the pooled, random and fixed effects estimations. The shape is quite different from one estimation to the other. The pooled estimation shows an increase in performance below 20 percent, followed by small concave bumps at 20 and 40 percent, in a relation that is mostly increasing until 40 percent and slightly decreasing thereafter. With random effects, we get an increase below 20 percent, and then a relatively flat curve.

We focus our attention on Figure $4 \mathrm{c}$ with fixed effects estimation, since fixed effects control for potentially endogenous time-invariant unobserved firm-level heterogeneity. The effect of ownership on performance is positive until about 75 or 80 percent and very slightly concave, with a less marked increase after 50 percent and eventually a small decrease between about 75 and 90 percent. These turning points occur at or around meaningful control thresholds in Belgian law. As mentioned in Section 3, according to Belgian law, a shareholder whose ownership reaches the threshold of 25 percent of voting rights gets an exemption of taxes on dividends. Thus, after 25 percent, the dominant shareholder has an incentive to act in such a way as to maximize firm value, in order to reap the benefits of the reduced taxation on their dividends 8 This contributes to the alignment of his interests with those of the dispersed shareholders. This positive effect at high levels of ownership is consistent with what Morck, Shleifer, and Vishny (1988) find in U.S. firms and is also in line with the literature that suggests that with higher levels of ownership, shareholders have the incentives to control managers (see for instance Shleifer and Vishny 1997). This seems to change when ownership reaches about 75 percent, which is the legal threshold after which a shareholder can change the legal statutes of the firm. Thus, after 75 percent,

\footnotetext{
${ }^{8}$ This tax exemption on dividends applies exclusively to individual shareholders (not voting blocks) that are moral, but not physical persons, and whose holdings exceed the threshold of $25 \%$ of a firm for more than one consecutive year. We have found that in $62.5 \%$ cases when the largest shareholder is in the $25 \%-27.5 \%$ range, the largest individual shareholder is a moral person who also holds more than $25 \%$ of the shares of the company, while this fraction is $46 \%$ for the $27.5 \%-30 \%$ range, and it increases to $89 \%$ for the $30 \%-32.5 \%$ range. Out of all firm year observations where the largest owner holds more than $25 \%$ of the shares of the company, the tax exemption applies to $89 \%$ of them. Thus, while the tax exemption argument does not systematically apply to all largest shareholders in the bracket of ownership above $25 \%$, it still applies to a very large majority of them.
} 
it is not entirely clear what the intentions of the shareholder are with the firm. He could be engaging in mergers and acquisition, or prepare to delist the firm, and this could explain the decrease in performance after that threshold. However, as we mention above, one should be careful when drawing conclusions, since at these extremes there are only few observations.

We now examine the results when we distinguish between family and non-family firms. Figures 5a and 5b clearly show the difference in the relation between ownership and performance between the two groups, which confirms previous findings in the literature about the specificity of family firms. Since it applies in the same way to all firms, an argument based exclusively on the legal control thresholds in Belgium cannot explain differences between both groups of firms.

It appears that for family firms, ownership has a positive effect on performance between 15 and 30 percent. From 30 to 40 percent, there seems to be a plateau, followed by a negative effect of ownership on performance, which starts out very weak between 30 and 45 percent and progressively becomes stronger. The curve eventually seems to increase again or stabilize at around 75 percent, and then decreases again for even higher levels of ownership concentration. The fact that the effect is first positive for small values of ownership concentration and then negative also explains why a linear model struggles to deliver a significant parameter. Indeed, one could think of the linear model as delivering an "average slope" over the whole range of values of ownership concentration, and therefore the positive and negative slopes will tend to cancel each other out. This biases the coefficient towards zero and adversely affects its significance. Figure $5 \mathrm{~b}$ shows a very different picture for non-family firms, with an overall increasing effect of ownership on performance up to 75 percent, and a number of tiny concave bumps around 20, 40, and 60 percent. Overall the shape is concave with a maximum reached at 75 percent, and a decrease between 75 and 85 percent of ownership, when the dominant shareholder has the power to modify the statutes of the firm. This slightly concave shape is qualitatively similar to the one found in U.S. firms for managerial ownership by McConnell and Servaes (1990), with a maximum around $49 \%$ in 1976 and $38 \%$ in 1986.

The finding in Figure $5 \mathrm{a}$ is compatible with several explanations. First, this is compatible with the existence of an entrenchment effect, which could explain the declining 
performance when ownership concentration is above 40 percent, and which becomes more pronounced, once the shareholder reaches absolute majority. It appears that with as little as 30 or 40 percent stakes in the firm, the shareholders of family firms are already powerful enough to extract rents and have a negative impact on firm value. Such an entrenchment effect has been found for a sample of continental European firms by Bennedsen and Meisner Nielsen (2010), as well as and in Morck, Strangeland, and Yeung (2000). This does not, however, explain the non-monotonicity in Figure 5a,

An alternative explanation is that families holding high stakes in a company are likely to hold all or a large part of their wealth invested in it, which results in under-diversification, and therefore high levels of risk aversion (see e.g. Demsetz and Lehn 1985). It is thus likely that the declining performance that we observe at high levels of ownership concentration results from the fact that dominant risk-averse family shareholders prefer to forego riskier investment opportunities, which eventually lowers firm performance. Since in principle the entrenchment explanation could apply in the same way to all firms, regardless of whether they are owned by families or not, the strong difference between family and non-family firms makes the risk-aversion explanation for the ownership performance pattern we observe in family firms more plausible.

A possible alternative explanation for the difference between family and non-family firms is provided by the Burkart, Panunzi, and Shleifer (2003) model, in which a retiring founder/manager of a family firm has to decide jointly about the fraction of the company's ownership he wants to retain, as well as whether to hire a professional manager or to leave management to his heirs. A professional manager is assumed to possess better skill than the heir. One of the model's predictions is that families with a lower level of ownership in the firm hire a professional manager, while families with higher level of ownership keep the management inside the family, for instance because of the amenity potential of the firm. Thus one possible explanation of the upward slope we observe in our nonparametric estimation for family firms with ownership between 15 and 30 percent could be that, like in the Burkart, Panunzi, and Shleifer (2003) model, family firms with lower levels of ownership are run by professionals who are better managers, while above a certain threshold (in our case about 30 percent) firms tend to be run by family members, which results in lower 
performance, because they lack the skill of a professional manager. Non-family firms on the other hand, exhibit a slightly nonlinear but overall upward trending pattern which is consistent with Burkart, Panunzi, and Shleifer (2003), since non-family firms are all managed by professionals, resulting in better performance.

We were able to find suggestive evidence that supports the Burkart, Panunzi, and Shleifer (2003) explanation by attempting to identify the family firms whose CEO is a family member. While we could not establish this systematically for all family firms, we nonetheless found this information for a large fraction $(68 \%)$ of our sample. This is very clear when the CEO has the same surname as the family that is known to control the firm. In some cases this is not so straightforward, since even with a different surname, the CEO could still belong to the extended controlling family. We found that out of the 44 firm year observations with shareholdings in the 10 to 30 percent range, where our curve is increasing, in $77.7 \%$ of the cases (34 observations), the firm is run by a professional manager unrelated to the family, while the CEO is a family member in $18.2 \%$ of the cases (8 observations), which leaves 2 firm year observations, where we could not find information. In contrast, in the 452 firm year observations where the largest shareholder is in the range above 30 percent, we found that the CEO is a family member in almost $56 \%$ of the cases (252 observations), while we could identify an external CEO in only $12.4 \%$ of the cases (56 observations), which leaves us with $31.9 \%$ of the cases (144 observations), where we could neither establish nor discard the possibility that the CEO is a family member. Thus even in the worst case scenario, if all unknown observations run against our explanation, we would be left with about $23 \%$ (56\%) family CEOs in firms below (above) the 30 percent threshold.

Finally, we check whether there are differences in the effect of ownership concentration on performance between firms related to coordination centers and those without such a link. Figures $5 \mathrm{c}$ and $5 \mathrm{~d}$ show an increasing relation, with differences only for very low levels of ownership concentration. Focusing on the 15 to 85 percent range, which is where the bulk of the observations lie, both curves are increasing with very similar slopes, except for the 15 to 20 percent range, which is decreasing for coordination center firms and increasing for firms without such an affiliation. Thus it seems that being related to a coordination center, which lets multinationals and their affiliates enjoy tax advantages in Belgium, does 
not have a strong impact on the ownership performance relation.

The results for the control variables are in line with the corporate finance literature. Size is inversely related to firm performance, long and short term debts impact performance negatively, indicating asymmetric information related to financing via debts. Investment in financial fixed assets variable, as well as capital expenditures have a positive effect on firm performance. Finally, R\&D expenditures have a positive effect on firm performance, as they signal good investment opportunities.

\section{Robustness}

We subject our results to a number of robustness checks.

\subsection{Accounting measure of performance}

First, we rerun our estimations with return on assets (RoA), an accounting measures of performance. Market-to-book value is the most frequently used dependent variable in ownership performance studies. It is a forward-looking market-based measure of firms' future performance, which assumes that markets are efficient and prices accurately reflect all available information. An alternative is to use an accounting-based measure of performance like Return on Assets (RoA). While market-based measures of performance can be noisy, accounting measures are backward-looking, since they are based on historical data; moreover they can be distorted by tax laws and accounting conventions and are subject to managerial manipulation (see e.g. Amit and Livnat 1989, Benston 1985, Fisher and McGowan 1983, Montgomery and Wernerfelt 1988). Thus, both market and accountingbased measures of performance have advantages and disadvantages, and they can offer complementary views on firm performance. Due to a number of missing values, our sample with RoA reduces to 918 firm year observations. While the correlation between market-tobook value and RoA in our data is positive, it is not extremely large: in the whole sample, this correlation is only 0.18. Thus, the accounting and market measures of performance clearly do not contain the same information and one should not expect to find exactly the same results. 
The parametric results shown in Panel A of Table 6 are similar in terms of signs, to the ones for market-to-book value: with fixed effects, there is an insignificant positive overall effect of ownership concentration on performance, which becomes negative insignificant for family firms but positive and significant for non-family firms. A decrease in significance when using RoA has also been found for the ownership performance relation, for instance in a study of Canadian firms by King and Santor (2008).

The results of the parametric part of the semiparametric estimation are shown in Panel B of Table 6], and the nonparametric fixed effects estimate of the effect of the largest shareholder on RoA is displayed in Column (b) of Figure 6. The results are qualitatively fairly similar to our base results with market-to-book value, shown in Column (a) for ease of comparison, especially when one restricts attention to the 15 to 85 percent range. For the whole sample, it seems that with RoA there is a more pronounced downward turn for very high levels of ownership than with market-to-book value. Such a difference in shape is consistent with Isakov and Weisskopf (2014) who use a quadratic specification and find different inflection points between RoA and market-to-book value in the ownership performance relation in a study of Swiss family firms. Like with market-to-book value, results with RoA are quite different between family and non-family firms. For family firms, the effect of concentration on performance is increasing at first between 15 and about 40 percent and then the relation is decreasing, but with a bump around 60 percent, while for non-family firms the effect is increasing until it reaches a maximum before 75 percent. Thus, overall, and especially given the weak correlation between RoA and market-to-book value, our results appear reasonably robust to the use of RoA as a measure of performance.

\subsection{Second largest shareholder}

We check the robustness of our results to the inclusion of a variable for the size of the second largest shareholder. According to the literature the existence of a second largest shareholder may have an effect on the control exercised by the largest one. For instance, using an event-study, von Lilienfeld-Toal and Schnitzler (2015) show that external blockholding by activist shareholders matters in a sample of U.S. listed firms.

In our Belgian data, in almost half of the firm/year observations there is no declared 
second shareholder, consistent with Zwiebel's (1995) theoretical model, in which the largest shareholder deters other shareholders from locating in the same firm. Moreover, when present, the second largest shareholder holds an average of only $5 \%$ shares, which is very small compared to the average of $54 \%$ shares held by the first largest one.

Panel A of Table 7 shows that in the parametric estimations, the second largest shareholder has no significant effect on performance, except a marginally significant effect (at $10 \%$ ) in non-family firms and a positive and significant effect in family firms. Note, however, that with a linear model, in family firms, it appears that the first largest owner has no effect, which is counterintuitive. This seems to be an artifact of the inability of the linear model to capture the effect of the first largest owner, due to the non-linearity of the effect, which disappears in the semiparametric results. This is confirmed in panel B of Table 7, which shows no statistically significant effect of the second largest shareholder on performance. Moreover, the nonparametric effect of the largest shareholder on performance is hardly affected by the inclusion of the second largest shareholder, as shown in Column (c) of Figure 6, which is nearly identical to our base results in Column (a) for the whole sample and the subsamples of family and non-family firms. Thus it seems that there is no consistant effect of the second largest shareholder on performance. This absence of effect is likely due to the very large size of the first largest owner in Belgium, which leaves little room for a second shareholder to influence the firm.

\section{Concluding Remarks}

In this paper we analyze levels of ownership concentration seldom considered before in the literature and we show how large controlling shareholders affect firm value. We use a unique detailed database on share ownership of Belgian listed firms which exhibit levels

of ownership concentration ignored in the literature. The very high levels of ownership concentration via the practices of voting blocks and/or business groups make Belgian listed firms a real laboratory to examine issues of ownership structure and performance. Our data set also makes it possible to investigate differences between family and non-family firms, or firms with or without a link to a coordination center. 
We use kernel-based local linear semiparametric pooled, random and fixed effects models to study the effect of very large controlling shareholders on firm performance. Using semiparametric models means that we do not impose any a priori functional form on the relation between the ownership and performance, which is important in this context, given how controversial this issue is in the empirical literature. As a matter of comparison we also use traditional parametric panel data models.

Our semiparametric results show important departures from linearity. In the full sample, the effect of ownership on performance is positive until about 75 or 80 percent and slightly concave. Many of the turning points we find in the full sample, or in the subsamples of family and non-family firms, seem to correspond to thresholds that are meaningful in terms of control, according to Belgian law.

The most interesting departure from linearity is in family firms, which exhibit a nonmonotonic ownership performance relation, that is first increasing until 30 percent and then starts decreasing from 40 percent onwards. We find that this non-linearity, captured by the nonparametric estimate, results in an insignificant coefficient in the parametric model. Moreover our results for family-firms are consistent with an explanation based on the risk-aversion of large family shareholders, which leads them to forego high-risk high-return projects, resulting in lower performance at higher levels of ownership. It is also consistent with the prediction of the Burkart, Panunzi, and Shleifer (2003) model, that firms keep management inside the family when they hold large positions, resulting in reduced performance, while they are more likely to rely on a professional CEO at lower levels of ownership, resulting in better performance. We find evidence that suggests that indeed, at low levels of family ownership concentration, firms rely more on external CEOs. 


\section{References}

Amit, R., and J. Livnat (1989): "Efficient Corporate Diversification: Methods and Implications," Management Science, 35, 879-897.

Anderson, R., And D. Reeb (2003): "Founding-Family Ownership and Firm Performance: Evidence from the S\&P 500," Journal of Finance, 58, 1301-1328.

Becht, M., And C. Mayer (2001): "The control of Corporate Europe," in The control of Corporate Europe, ed. by F. Barca, and B. Marco, ECGN, chap. 1, pp. 1-45. Oxford University Press.

Bennedsen, M., and K. Meisner Nielsen (2010): "Incentive and Entrenchment Effects in European Ownership," Journal of Banking and Finance, 34, 2212-2229.

Bennedsen, M., K. Meisner Nielsen, F. Perez-Gonzalez, and D. Wolfenzon (2007): "Inside The Family Firm: The Role Of Families In Succession Decisions And Performance," Quarterly Journal of Economics, 122(2), 647-691.

Benston, G. (1985): "The Validity of Profits-Structure Studies with Particular Reference to the Ftc'S Line-Of-Business Data," American Economic Review, 75, 3767.

Berle, A. A., And G. C. Means (1932): The Modern Corporation and Private Property. Macmillan, New York.

Burkart, M., F. Panunzi, and A. Shleifer (2003): "Family Firms," Journal of Finance, LVIII(5), 2167-2201.

Chen, G., M. Firth, and L. Xu (2009): "Does the Type of Ownership Control Matter? Evidence from China's Listed Companies," Journal of Banking and Finance, 33, 171181.

Chen, J., And B. Dong (2012): "A Nonparametric Estimation on the Effects of Import and Export Trade to Economic Growth in China," Procedia Engineering, 29, 952-956.

Chen, S.-S., K. W. Ho, C.-F. Lee, And K. Shrestha (2004): "Nonlinear Models in Corporate Finance Research: Review, Critique, and Extensions," Review of Quantitative Finance and Accounting, 22, 141-169. 
Chо, M.-H. (1998): "Ownership structure, investment, and the corporate value: an empirical analysis," Journal of Financial Economics, 47, 103-121.

Claessens, S., S. Djankov, J. Fan, and L. H. Lang (2002): "Disentangling the Incentive and the Entrenchment Effects of Large Shareholders," Journal of Finance, 57, $2741-2771$.

Claessens, S., S. Duankov, and L. H. Lang (2000): "The separation of Ownership and Control in East Asian Corporations," Journal of Financial Economics, 58, 81-112.

Coenjaerts, T., S. Buron, C. Charlot, and V. Halloy (2007): "Le Classement annuel des fortunes professionnelles," Trends-Tendances, 32(41).

Cronqvist, H., and R. Fahlenbrach (2008): "Large Shareholders and Corporate Policies," Review of Financial Studies, 22(10), 3941-3976.

CUi, H., AND Y. MAK (2002): "The relationship between managerial ownership and firm performance in high R\&D firms," Journal of Corporate Finance, 8, 313-336.

Davies, J., D. Hillier, and P. McColgan (2005): "Ownership structure managerial behavior and corporate value," Journal of Corporate Finance, 11, 645-660.

De Angelo, H., And L. De Angelo (2000): "Controlling Stockholders and the Disciplinary Role of Corporate Payout Policy: A Study of the Times Mirror Company," Journal of Financial Economics, 56, 153-207.

Demsetz, H. (1983): "The Structure of Ownership and the Theory of the Firm," Journal of Law and Economics, 26, 375-390.

Demsetz, H., and K. Lehn (1985): "The Structure of Corporate Ownership: Causes and Consequences," Journal of Political Economy, 96(6), 1155-1177.

Demsetz, H., and B. Villalonga (2001): "Ownership Structure and Corporate Performance," Journal of Corporate Finance, 7, 209-233.

Denis, K., D., And J. McConnell, J. (2003): "International Corporate Governance," Journal of Financial and Quantitative Analysis, 38(01), 1-36.

Faccio, M., and L. Lang (2002): "The Ultimate Ownership of Western European Corporations," Journal of Financial Economics, 65(3), 365-395. 
Fisher, F. M., And J. J. McGowan (1983): "On the Misuse of Accounting Rates of Return to Infer Monopoly Profits," American Economic Review, 73, 82-97.

Florackis, C., A. Kostakis, and A. Ozkan (2009): "Managerial Ownership and Performance," Journal of Business Research, 62, 1350-1357.

Franks, J., And C. MAyer (1995): "Ownership and Control," in Trends in Business Organization: Do Participation and Cooperation Increase Competitiveness? An International Workshop. Kiel Institute of World Economics, ed. by H. Siebert. Tübingen: J.C.B. Mohr.

Franks, J., C. Mayer, P. Volpin, and H. Wagner, F. (2012): "The life cycle of family ownership: International evidence," Review of Financial Studies, 25(6), 1675-1712.

Gorton, G., And F. A. Schmid (2000): "Universal Banking and the Performance of German Firms," Journal of Financial Economics, 58, 29-80.

Henderson, D. J., R. J. Carroll, and Q. Li (2008): "Nonparametric Estimation and Testing of Fixed Effects Panel Data Models," Journal of Econometrics, 144, 257-275.

Henderson, D. J., And A. Ullah (2005): “A Nonparametric Random Effects Estimator," Economics Letters, 88, 403-407.

Hermalin, B. E., And M. S. Weisbach (1991): "The relationship between managerial ownership and firm performance in high R\&D firms," Financial Management, 20(4), $101-112$.

Holderness, C., and D. Sheehan (1988): "The Role of Majority Shareholders in Publicly Held Corporations: An Exploratory Analysis," Journal of Financial Economics, $20,317-346$.

Holderness, C. G. (2003): "A Survey of Blockholders and Corporate Control," Federal Reserve Bank of New York Economic Policy Review, 9(1), 51-64.

— (2009): "The Myth of Diffuse Ownership in the United States," Review of Financial Studies, 22(4), 1377-1408. 
Isakov, D., AND J.-P. Weisskopf (2014): “Are Founding Families Special Blockholders? An Investigation of Controlling Shareholder Influence on Firm Performance," Journal of Banking and Finance, 41, 1-16.

James, H. (1999): "Owner as Manager, Extended Horizons and the Family Firm," International Journal of the Economics of Business, 6, 41-56.

Jensen, M. C., And W. H. Meckling (1976): "Theory of the Firm: Managerial Behavior, Agency Costs, and Ownership Structure," Journal of Financial Economics, 3(4), 305360.

Johnson, S., R. La Porta, F. Lopez-De-Silanes, and A. Shleifer (2000): "Tunneling," American Economic Review, 90(2), 22-27.

Kan, K., And M.-J. Lee (2012): "Lose Weight For a Raise If Overweight: Marginal Integration for Semi-Linear Panel Models," Journal of Applied Econometrics, 27, $666-685$

King, M. R., And E. SAntor (2008): "Family Values: Ownership Structure, Performance and Capital Structure of Canadian Firms," Journal of Banking and Finance, 32, $2423-2432$.

La Porta, R., F. Lopez-de Silanes, and A. Shleifer (1999): "Corporate Ownership Around the World," Journal of Finance, LIV(2), 471-517.

La Porta, R., F. Lopez-de Silanes, A. Shleifer, and R. Vishny (2000): "Investor Protection and Corporate Governance," Journal of Financial Economics, 58, 3-27.

Leech, D. (2002): "Shareholder Voting Power and Ownership Control of Companies," Homo Oeconomicus, XIX(3), 345-373.

Li, A., And T. Stengos (1996): "Semiparametric Estimation of Partially Linear Panel Data Models," Journal of Econometrics, 71, 389-397.

Lin, X., and R. Carroll (2000): "Nonparametric Estimation for Clustered Data When the Predictor is Measured Without/With Error," Journal of the American Statistical Association, 95(450), 520-534. 
Lin, X., and R. Carroll (2001): "Semiparametric Regression for Clustered Data Using Generalized Estimating Equations," Journal of the American Statistical Association, 96(455), 2045-1056.

Lin, X., and R. Carroll (2006): "Semiparametric Estimation in General Repeated Measures Problems," Journal of the Royal Statistical Society B, 68(69-88).

Maury, B. (2006): "Family Ownership and Firm Performance: Empirical Evidence from Western European Corporations," Journal of Corporate Finance, 12, 321-341.

McConnell, and Servaes (1990): "Additional Evidence on Equity Ownership and Corporate Value," Journal of Financial Economics, 27, 595-612.

Montgomery, C., and B. Wernerfelt (1988): "Diversification, Ricardian Rents, and Tobins q," Rand Journal of Economics, 19, 623-632.

Morck, R., A. Shleifer, and R. W. Vishny (1988): "Management, Ownership and Market Valuation: An Empirical Analysis," Journal of Financial Economics, 20, $293-315$.

Morck, R., D. Strangeland, and B. Yeung (2000): "Inherited Wealth, Corporate Control, and Economic Growth The Canadian Disease?," in Concentrated Corporate Ownership, chap. 11, pp. 319-372. National Bureau of Economic Research, Inc.

SARkar, J., And S. SARKar (2000): "Large Shareholder Activism in Corporate Governance in Developing Countries: Evidence from India," International Review of Finance, 1, 161-194.

Shleifer, A., And R. W. Vishny (1986): "Large Shareholders and Corporate Control," Journal of Political Economy, 95, 461-488.

(1997): “A Survey of Corporate Governance," Journal of Finance, 52(2), 737-783.

Short, H., And K. KeAsey (1999): "Managerial ownership and the performance of firms: evidence from the UK," Journal of Corporate Finance, 5, 79-101.

Sraer, D., And D. Thesmar (2007): "Performance and Behavior of Family Firms: Evidence from the French Stock Market," Journal of the European Economic Association, $5(4), 709-751$. 
Stulz, R. (1988): "Managerial control of voting rights: Financing policies and the market for corporate control," Journal of Financial Economics, 20, 25-54.

Su, L., And A. Ullah (2006): "Profile Likelihood Estimation of Partially Linear Panel Data Models with Fixed Effects," Economics Letters, 92, 75-81.

Ullah, A., And N. Roy (1998): "Nonparametric and Semiparametric Econometrics of Panel Data," in Handbook of Applied Economic Statistics, ed. by A. Ullah, and D. Giles, vol. 1, pp. 579-604. Marcel Dekker New York.

Villalonga, B., And R. Amit (2006): "How Do Family Ownership, Control and Management Affect Firm Value?," Journal of Financial Economics, 80, 385-417.

von Lilienfeld-Toal, U., And J. Schnitzler (2015): "What Matters for Investor Activism: An Investigation of Activists' Incentives vs. Activist Types," mimeo.

WAng, N. (2003): "Marginal Nonparametric Kernel regression Accounting for WithinSubject Correlation," Biometrika, 90, 43-52.

Wang, N., R. Carroll, and X. Lin (2005): "Efficient Semiparametric Marginal Estimation for Longitudinal/Clustered Data," Journal of the American Statistical Association, 100(469), 147-157.

Xu, X., and Y. WAng (1999): "Ownership Structure and Corporate Governance in Chinese Stock Companies," China Economic Review, 10, 75-98.

Zhou, X., And K.-W. Li (2011): "Inequality and Development: Evidence from Semiparametric Estimation with Panel Data," Economics Letters, 113, 203-207.

Zwiebel, J. (1995): "Block Investment and Partial Benefits of Corporate Control," Review of Economic Studies, 62, 161-185. 
Table 1: Variable Definition

\begin{tabular}{lcl}
\hline \multicolumn{1}{c}{ Variable name } & Explanation & \multicolumn{1}{c}{ Sources } \\
\hline $\begin{array}{l}\text { Market-to-book value } \\
\text { (Tobin's q) }\end{array}$ & Year end market capitalization to total assets & $\begin{array}{l}\text { Year end market capitalization } \\
\text { is available from Brussels Stock } \\
\text { Exchange. }\end{array}$ \\
& & \\
RoA & Net income to total assets & $\begin{array}{l}\text { From 1991 to 1996 we use } \\
\text { the National Bank of Belgium }\end{array}$ \\
& & $\begin{array}{l}\text { Centrale des Bilans" data and } \\
\text { from 1997 to 2006 we rely on } \\
\text { the "Belfirst" database of Bu- } \\
\text { reau Van Dijk. }\end{array}$
\end{tabular}

Ownership measures

\begin{tabular}{|c|c|}
\hline Single shareholder & $\begin{array}{l}\text { Share ownership of each declared shareholder in a firm } \\
\text { considered individually, regardless of her/his size (this } \\
\text { means that there can be more than one in each firm at } \\
\text { each point in time). }\end{array}$ \\
\hline $\begin{array}{lr}\text { Largest } & \text { shareholder } \\
\text { (without } & \text { voting } \\
\text { blocks) } & \end{array}$ & $\begin{array}{l}\text { Shareholdings of the largest single shareholders for each } \\
\text { firm and each year. }\end{array}$ \\
\hline Largest shareholder & $\begin{array}{l}\text { Shareholdings of the largest single shareholders for each } \\
\text { firm and each year, after aggregating up the shares of } \\
\text { all shareholders in the same business group and/or the } \\
\text { same voting block and treating them as if they were one } \\
\text { shareholder. }\end{array}$ \\
\hline $\begin{array}{l}\text { Second Largest share- } \\
\text { holder }\end{array}$ & $\begin{array}{l}\text { Shareholdings of the second largest shareholder (when- } \\
\text { ever present, otherwise zero) for each firm and each year, } \\
\text { after aggregating up the shares of all shareholders in the } \\
\text { same business group and/or the same voting block and } \\
\text { treating them as if they were one shareholder. }\end{array}$ \\
\hline
\end{tabular}

Control variables

Size (in log) Log of total assets.

Long term debt Long term assets to total assets.

For all control variables, same data sources as for RoA.

Short term debt

Short term assets to total assets.

We use several sources:

(1) annual reports of listed firms;

(2) notifications available in the Documentation and Statistics Department of the Brussels Stock Exchange; and (3) yearly publications of the shareholdings of Belgian listed firms from the "Research and Strategy Department Equity Research" at ING bank (previously BBL).

Financial fixed assets Investment in financial fixed assets divided by total assets. The investment in financial fixed assets is equal to the amounts invested by the firm in tied firms and firms with which there exists a participation link to total assets. The firms tied to another firm are: the firms that control it, the firms that it controls, the firms with which it forms a consortium, the other firms that, to the knowledge of the board, are controlled by one of the firms mentioned above. The firms with which there exists a participation link are the firms, other than tied firms, in which the firm or its subsidiary holds a direct or indirect participation.

Capital expenditures New investments normalized by total assets. 
Table 2: Descriptive statistics (Firm/year observations)

\begin{tabular}{|c|c|c|c|c|c|c|c|}
\hline \multirow[b]{2}{*}{ Variable } & \multirow{2}{*}{$\begin{array}{c}\text { Whole sample } \\
\mathrm{N}=1676\end{array}$} & \multicolumn{2}{|c|}{ Family vs. Non-family } & \multirow{2}{*}{$\begin{array}{c}\text { Difference } \\
(\mathrm{t} \text { test }) \\
\mathrm{p} \text {-value } \\
\end{array}$} & \multirow{2}{*}{\multicolumn{2}{|c|}{$\begin{array}{cc}\text { CC firms vs. } & \text { Non-CC } \\
\mathrm{CC} & \text { Non-CC } \\
\mathrm{N}=531 & \mathrm{~N}=1145 \\
\end{array}$}} & \multirow{2}{*}{ 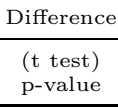 } \\
\hline & & $\begin{array}{l}\text { Family } \\
\mathrm{N}=544\end{array}$ & $\begin{array}{c}\text { Non-family } \\
\mathrm{N}=1132\end{array}$ & & & & \\
\hline \multicolumn{8}{|c|}{ Performance measures } \\
\hline $\begin{array}{l}\text { Market-to-book value } \\
\text { (Tobin's q) }\end{array}$ & $\begin{array}{c}1.1451 \\
(0.8809)\end{array}$ & $\begin{array}{c}1.4065 \\
(1.0785)\end{array}$ & $\begin{array}{c}1.0195 \\
(0.8058)\end{array}$ & $<.01$ & $\begin{array}{c}1.1201 \\
(0.9132)\end{array}$ & $\begin{array}{c}1.1567 \\
(0.8756)\end{array}$ & 0.4639 \\
\hline RoA & $\begin{array}{c}(\mathrm{N}=918) \\
0.0344 \\
(0.0343)\end{array}$ & $\begin{array}{c}(\mathrm{N}=367) \\
0.0417 \\
(0.0360)\end{array}$ & $\begin{array}{c}(\mathrm{N}=551) \\
0.0295 \\
(0.0332)\end{array}$ & 0.1260 & $\begin{array}{c}(\mathrm{N}=293) \\
0.0384 \\
(0.0348)\end{array}$ & $\begin{array}{c}(\mathrm{N}=625) \\
0.0325 \\
(0.0337)\end{array}$ & 0.4849 \\
\hline \multicolumn{8}{|c|}{ Ownership measures } \\
\hline $\begin{array}{l}\text { Single shareholder (re- } \\
\text { gardless of size) }\end{array}$ & $\begin{array}{c}0.1392 \\
(0.0516)\end{array}$ & $\begin{array}{c}0.1329 \\
(0.0512)\end{array}$ & $\begin{array}{c}0.1426 \\
(0.0517)\end{array}$ & 0.0403 & $\begin{array}{c}0.1066 \\
(0.0316)\end{array}$ & $\begin{array}{c}0.1588 \\
(0.0679)\end{array}$ & $<0.01$ \\
\hline $\begin{array}{l}\text { Largest shareholder } \\
\text { (without voting blocks) }\end{array}$ & $\begin{array}{c}0.4334 \\
(0.4186)\end{array}$ & $\begin{array}{c}0.4279 \\
(0.3993)\end{array}$ & $\begin{array}{c}0.4360 \\
(0.4375)\end{array}$ & 0.4652 & $\begin{array}{c}0.4050 \\
(0.3800)\end{array}$ & $\begin{array}{c}0.4465 \\
(0.4509)\end{array}$ & $<.01$ \\
\hline $\begin{array}{l}\text { Largest shareholder } \\
\text { (with voting blocks) }\end{array}$ & $\begin{array}{l}0.5452 \\
(0.5455)\end{array}$ & $\begin{array}{l}0.5626 \\
(0.5608)\end{array}$ & $\begin{array}{c}0.5369 \\
(0.5356)\end{array}$ & 0.0172 & $\begin{array}{c}0.4970 \\
(0.5010)\end{array}$ & $\begin{array}{c}0.5676 \\
(0.5686)\end{array}$ & $<.01$ \\
\hline $\begin{array}{l}\text { Second Largest share- } \\
\text { holder }\end{array}$ & $\begin{array}{c}0.0522 \\
(0.0047)\end{array}$ & $\begin{array}{c}0.0548 \\
(0.0294)\end{array}$ & $\begin{array}{c}0.0510 \\
(0.0000)\end{array}$ & 0.3528 & $\begin{array}{c}0.0508 \\
(0.0260)\end{array}$ & $\begin{array}{c}0.0528 \\
(0.0000)\end{array}$ & 0.6334 \\
\hline \multicolumn{8}{|c|}{ Control variables } \\
\hline Size (in log) & $\begin{array}{c}18.7117 \\
(18.4616)\end{array}$ & $\begin{array}{c}18.7753 \\
(18.4237)\end{array}$ & $\begin{array}{c}18.6812 \\
(18.4845)\end{array}$ & 0.3363 & $\begin{array}{c}20.2708 \\
(20.5121)\end{array}$ & $\begin{array}{c}17.9887 \\
(17.9798)\end{array}$ & $<.01$ \\
\hline Long term debt & $\begin{array}{c}0.1138 \\
(0.0553)\end{array}$ & $\begin{array}{c}0.1062 \\
(0.0658)\end{array}$ & $\begin{array}{c}0.1175 \\
(0.0495)\end{array}$ & 0.1584 & $\begin{array}{c}0.1600 \\
(0.1278)\end{array}$ & $\begin{array}{c}0.0925 \\
(0.0189)\end{array}$ & $<.01$ \\
\hline Short term debt & $\begin{array}{c}0.2581 \\
(0.2169)\end{array}$ & $\begin{array}{c}0.2710 \\
(0.2260)\end{array}$ & $\begin{array}{c}0.2520 \\
(0.2120)\end{array}$ & 0.0816 & $\begin{array}{l}0.2779 \\
(0.2425)\end{array}$ & $\begin{array}{c}0.2490 \\
(0.1974)\end{array}$ & $<.01$ \\
\hline Financial fixed assets & $\begin{array}{c}0.4777 \\
(0.5120)\end{array}$ & $\begin{array}{c}0.4865 \\
(0.5171)\end{array}$ & $\begin{array}{c}0.4734 \\
(0.5047)\end{array}$ & 0.4061 & $\begin{array}{c}0.6200 \\
(0.6422)\end{array}$ & $\begin{array}{c}0.4117 \\
(0.3902)\end{array}$ & $<.01$ \\
\hline Capital expenditures & $\begin{array}{c}0.0173 \\
(0.0005)\end{array}$ & $\begin{array}{c}0.0172 \\
(0.0008)\end{array}$ & $\begin{array}{c}0.0173 \\
(0.0004)\end{array}$ & 0.9713 & $\begin{array}{c}0.0156 \\
(0.0036)\end{array}$ & $\begin{array}{c}0.0181 \\
(0.0001)\end{array}$ & 0.3576 \\
\hline$R \& D$ & $\begin{array}{c}0.0025 \\
(0.0000)\end{array}$ & $\begin{array}{c}0.0028 \\
(0.0000)\end{array}$ & $\begin{array}{c}0.0023 \\
(0.0000)\end{array}$ & 0.5522 & $\begin{array}{c}0.0042 \\
(0.0000)\end{array}$ & $\begin{array}{l}0.0017 \\
(0.0000)\end{array}$ & $<.01$ \\
\hline
\end{tabular}

This table contains means (and medians between brackets) of the variables we use, as well as t statistics of the test of the null hypothesis that means are equal across groups. Market-to-book value (Tobin's q) is the proxy we use for firm value. RoA is return on assets. The number of observations for RoA is 918, 367, 551, 293, and 625 for the whole sample, family firms, non-families, firms related to coordination centers (CC), and not related to CC, respectively. Single shareholder is the percentage of share ownership of all declared shareholders, regardless of their size. There can be several shareholders in the same firm and therefore the number of observations for this variable is 7575 in the whole sample, 2650 and 4925 for family and non-family firms respectively, 2839 and 4736 for firms with and without a link to a coordination center. Largest shareholder (without voting blocks) is the percentage of share holdings of the largest shareholder, without aggregating votes in the same voting block. Largest shareholder (with voting blocks) is the percentage of share holdings of the largest shareholder, after aggregation of all votes that belong to the same voting block. Second Largest shareholder is the percentage share holdings of the second largest shareholder. Size is the log of total assets. Long term and short term debt are divided by total assets. Financial fixed assets variable represents investment in financial fixed assets divided by total assets. Capital expenditures variable represents new acquisitions divided by total assets. R\&D expenditures are also normalized by total assets. 
Table 3: Frequency of the number of different categories of shareholders per firm (in terms of firm year observations)

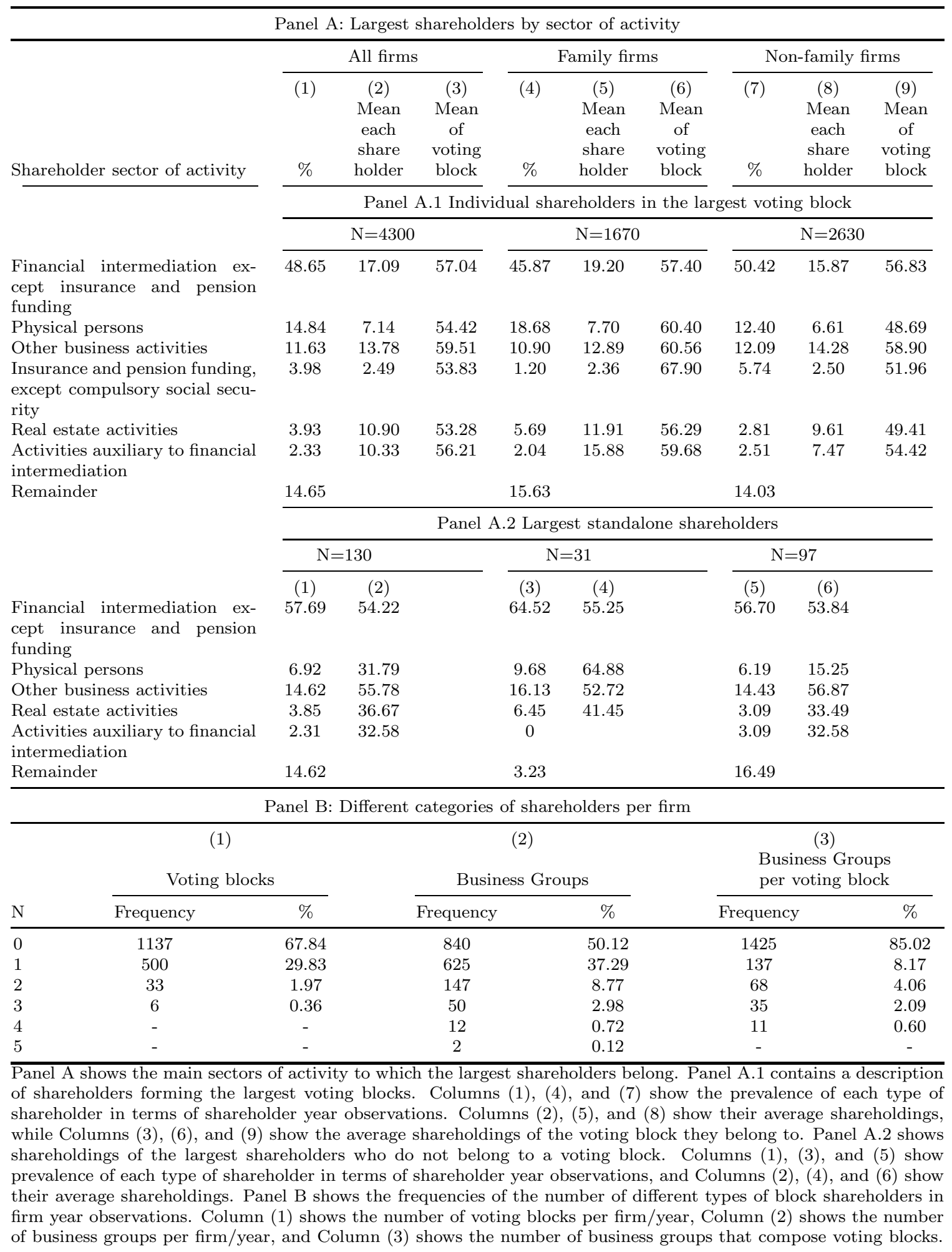


Table 4: The effect of concentration on firm performance: whole sample and family firms.

\begin{tabular}{|c|c|c|c|c|c|c|c|c|c|}
\hline & \multicolumn{9}{|c|}{ Market-to-book value } \\
\hline & \multicolumn{3}{|c|}{$\begin{array}{l}\text { Whole Sample } \\
\mathrm{N}=1676\end{array}$} & \multicolumn{3}{|c|}{$\begin{array}{c}\text { Family firms } \\
\mathrm{N}=544\end{array}$} & \multicolumn{3}{|c|}{$\begin{array}{c}\text { Non-family firms } \\
\mathrm{N}=1132\end{array}$} \\
\hline & $\begin{array}{c}(1) \\
\text { Pooled }\end{array}$ & $\begin{array}{l}(2) \\
\mathrm{FE}\end{array}$ & $\begin{array}{l}(3) \\
\mathrm{RE}\end{array}$ & $\begin{array}{c}(4) \\
\text { Pooled }\end{array}$ & $\begin{array}{l}(5) \\
\mathrm{FE}\end{array}$ & $\begin{array}{l}(6) \\
\mathrm{RE}\end{array}$ & $\begin{array}{c}(7) \\
\text { Pooled }\end{array}$ & $\begin{array}{l}(8) \\
\mathrm{FE}\end{array}$ & $\begin{array}{l}(9) \\
\mathrm{RE}\end{array}$ \\
\hline \multicolumn{10}{|c|}{ Panel A: Parametric models } \\
\hline Largest shareholder & $\begin{array}{c}-0.184^{*} \\
(0.110)\end{array}$ & $\begin{array}{c}0.332^{* *} \\
(0.129)\end{array}$ & $\begin{array}{c}0.143 \\
(0.121)\end{array}$ & $\begin{array}{c}-0.019 \\
(0.268)\end{array}$ & $\begin{array}{c}-0.390 \\
(0.310)\end{array}$ & $\begin{array}{c}-0.403 \\
(0.292)\end{array}$ & $\begin{array}{c}-0.267^{* *} \\
(0.118)\end{array}$ & $\begin{array}{c}0.399^{* * *} \\
(0.134)\end{array}$ & $\begin{array}{c}0.247^{* *} \\
(0.123)\end{array}$ \\
\hline Size & $\begin{array}{l}-0.042^{* * *} \\
(0.013)\end{array}$ & $\begin{array}{l}-0.375^{* * *} \\
(0.032)\end{array}$ & $\begin{array}{l}-0.200 * * * \\
(0.023)\end{array}$ & $\begin{array}{l}-0.043 \\
(0.033)\end{array}$ & $\begin{array}{l}-0.608 * * * \\
(0.072)\end{array}$ & $\begin{array}{c}-0.314^{* * *} \\
(0.054)\end{array}$ & $\begin{array}{l}-0.047 * * * \\
(0.015)\end{array}$ & $\begin{array}{l}-0.251^{* * *} \\
(0.036)\end{array}$ & $\begin{array}{c}-0.128^{* * *} \\
(0.024)\end{array}$ \\
\hline Short term debt & $\begin{array}{c}-0.504^{* *} \\
(0.230)\end{array}$ & $\begin{array}{l}-0.297^{* * *} \\
(0.112)\end{array}$ & $\begin{array}{l}-0.317^{* * *} \\
(0.105)\end{array}$ & $\begin{array}{l}-0.698^{* * *} \\
(0.229)\end{array}$ & $\begin{array}{l}-1.065^{* * *} * \\
(0.280)\end{array}$ & $\begin{array}{c}-0.930 * * * \\
(0.263)\end{array}$ & $\begin{array}{l}-0.422 \\
(0.305)\end{array}$ & $\begin{array}{l}-0.072 \\
(0.117)\end{array}$ & $\begin{array}{l}-0.132 \\
(0.108)\end{array}$ \\
\hline Long term debt & $\begin{array}{l}-0.745^{* * *} \\
(0.144)\end{array}$ & $\begin{array}{c}-1.147^{* * *} \\
(0.148)\end{array}$ & $\begin{array}{l}-1.012^{* * *} \\
(0.143)\end{array}$ & $\begin{array}{c}-1.689 * * * \\
(0.340)\end{array}$ & $\begin{array}{c}-1.938^{* * *} \\
(0.368)\end{array}$ & $\begin{array}{c}-1.662 * * * \\
(0.360)\end{array}$ & $\begin{array}{l}-0.547^{* * * *} \\
(0.155)\end{array}$ & $\begin{array}{c}-0.917 * * * \\
(0.154)\end{array}$ & $\begin{array}{c}-0.805^{* * *} \\
(0.145)\end{array}$ \\
\hline Financial fixed assets & $\begin{array}{l}0.167^{*} \\
(0.090)\end{array}$ & $\begin{array}{l}0.185^{*} \\
(0.098)\end{array}$ & $\begin{array}{l}0.157^{*} \\
(0.093)\end{array}$ & $\begin{array}{l}-0.309 \\
(0.208)\end{array}$ & $\begin{array}{l}-0.285 \\
(0.222)\end{array}$ & $\begin{array}{l}-0.312 \\
(0.209)\end{array}$ & $\begin{array}{c}0.360^{* * *} \\
(0.089)\end{array}$ & $\begin{array}{c}0.390^{* * *} \\
(0.104)\end{array}$ & $\begin{array}{c}0.382^{* * * *} \\
(0.097)\end{array}$ \\
\hline Capital expenditures & $\begin{array}{c}1.665^{* *} \\
(0.664)\end{array}$ & $\begin{array}{c}0.643^{* *} \\
(0.305)\end{array}$ & $\begin{array}{c}0.653^{* *} \\
(0.311)\end{array}$ & $\begin{array}{c}5.130^{* * *} \\
(1.286)\end{array}$ & $\begin{array}{c}0.286 \\
(1.178)\end{array}$ & $\begin{array}{c}1.193 \\
(1.196)\end{array}$ & $\begin{array}{l}1.264^{* *} \\
(0.524)\end{array}$ & $\begin{array}{c}0.597^{* *} \\
(0.287)\end{array}$ & $\begin{array}{c}0.613^{* *} \\
(0.287)\end{array}$ \\
\hline $\mathrm{R} \& \mathrm{D}$ & $\begin{array}{c}7.976^{* *} \\
(3.295)\end{array}$ & $\begin{array}{c}5.527^{* *} \\
(2.734)\end{array}$ & $\begin{array}{l}4.067^{* *} \\
(1.642)\end{array}$ & $\begin{array}{c}18.640 * * * \\
(4.413)\end{array}$ & $\begin{array}{c}17.493^{* * *} \\
(6.173)\end{array}$ & $\begin{array}{c}21.642^{* * *} \\
(5.728)\end{array}$ & $\begin{array}{c}5.724^{* *} \\
(2.671)\end{array}$ & $\begin{array}{c}1.751 \\
(2.819)\end{array}$ & $\begin{array}{l}2.648^{*} \\
(1.541)\end{array}$ \\
\hline $\begin{array}{l}\text { Year dummies } \\
\text { R-squared }\end{array}$ & $\begin{array}{l}\text { Yes } \\
0.120\end{array}$ & $\begin{array}{l}\text { Yes } \\
0.271\end{array}$ & Yes & $\begin{array}{c}\text { Yes } \\
0.199\end{array}$ & $\begin{array}{c}\text { Yes } \\
0.395\end{array}$ & Yes & $\begin{array}{l}\text { Yes } \\
0.125\end{array}$ & $\begin{array}{c}\text { Yes } \\
0.244\end{array}$ & Yes \\
\hline$\overline{\text { Size }}$ & $\begin{array}{c}-0.043^{* * *} \\
(0.013)\end{array}$ & $\begin{array}{c}-0.377^{* * *} \\
(0.035)\end{array}$ & $\begin{array}{c}-0.126^{* * *} \\
(0.028)\end{array}$ & $\begin{array}{c}-0.092^{* * *} \\
(0.025)\end{array}$ & $\begin{array}{c}-0.439^{* * *} \\
(0.058)\end{array}$ & $\begin{array}{c}-0.188^{* * *} \\
(0.048)\end{array}$ & $\begin{array}{l}-0.04^{*} \\
(0.02)\end{array}$ & $\begin{array}{c}-0.308^{* * *} \\
(0.042)\end{array}$ & $\begin{array}{c}-0.128^{* * *} \\
(0.039)\end{array}$ \\
\hline Short term debt & $\begin{array}{c}-0.497^{* * *} \\
(0.11)\end{array}$ & $\begin{array}{c}-0.293^{* *} \\
(0.121)\end{array}$ & $\begin{array}{c}-0.332^{* *} \\
(0.156)\end{array}$ & $\begin{array}{c}-0.501^{* *} \\
(0.22)\end{array}$ & $\begin{array}{c}-1.048^{* * *} \\
(0.216)\end{array}$ & $\begin{array}{c}-0.923^{* * *} \\
(0.29)\end{array}$ & $\begin{array}{c}-0.387^{* * *} \\
(0.133)\end{array}$ & $\begin{array}{c}0.011 \\
(0.146)\end{array}$ & $\begin{array}{l}-0.119 \\
(0.185)\end{array}$ \\
\hline Long term debt & $\begin{array}{c}-0.758^{* * *} \\
(0.15)\end{array}$ & $\begin{array}{c}-1.129^{* * *} \\
(0.161)\end{array}$ & $\begin{array}{c}-0.912^{* * *} \\
(0.214)\end{array}$ & $\begin{array}{c}-0.625^{* * *} \\
(0.212)\end{array}$ & $\begin{array}{c}-1.588^{* * *} \\
(0.233)\end{array}$ & $\begin{array}{c}-1.201^{* * *} \\
(0.293)\end{array}$ & $\begin{array}{c}-0.778^{* * *} \\
(0.21)\end{array}$ & $\begin{array}{c}-0.873^{* * *} \\
(0.212)\end{array}$ & $\begin{array}{c}-0.734^{* *} \\
(0.289)\end{array}$ \\
\hline Financial fixed assets & $\begin{array}{c}0.199^{* *} \\
(0.083)\end{array}$ & $\begin{array}{l}0.189^{*} \\
(0.107)\end{array}$ & $\begin{array}{c}0.141 \\
(0.134)\end{array}$ & $\begin{array}{c}0.26 \\
(0.184)\end{array}$ & $\begin{array}{c}0.207 \\
(0.195)\end{array}$ & $\begin{array}{c}0.12 \\
(0.248)\end{array}$ & $\begin{array}{l}0.174^{*} \\
(0.098)\end{array}$ & $\begin{array}{c}0.06 \\
(0.129)\end{array}$ & $\begin{array}{c}0.072 \\
(0.161)\end{array}$ \\
\hline Capital expenditures & $\begin{array}{c}1.679^{* * *} \\
(0.453)\end{array}$ & $\begin{array}{c}0.688^{* *} \\
(0.332)\end{array}$ & $\begin{array}{c}0.811 \\
(0.495)\end{array}$ & $\begin{array}{c}3.612^{* *} \\
(1.549)\end{array}$ & $\begin{array}{c}0.149 \\
(1.174)\end{array}$ & $\begin{array}{c}0.423 \\
(1.719)\end{array}$ & $\begin{array}{c}1.48^{* * *} \\
(0.489)\end{array}$ & $\begin{array}{c}0.715^{* *} \\
(0.351)\end{array}$ & $\begin{array}{l}0.858 \\
(0.53)\end{array}$ \\
\hline $\mathrm{R} \& \mathrm{D}$ & $\begin{array}{c}7.948^{* * *} \\
(1.477)\end{array}$ & $\begin{array}{l}5.413^{*} \\
(2.954)\end{array}$ & $\begin{array}{l}4.53^{* *} \\
(2.125)\end{array}$ & $\begin{array}{c}18.471^{* * *} \\
(2.752)\end{array}$ & $\begin{array}{c}14.075 * * * \\
(5.319)\end{array}$ & $\begin{array}{c}19.635^{* * *} \\
\quad(5.34)\end{array}$ & $\begin{array}{l}3.533^{*} \\
(1.814)\end{array}$ & $\begin{array}{c}3.62 \\
(3.483)\end{array}$ & $\begin{array}{l}2.001 \\
(2.362)\end{array}$ \\
\hline Year dummies & Yes & Yes & Yes & Yes & Yes & Yes & Yes & Yes & Yes \\
\hline R-squared & 0.127 & 0.736 & & 0.28 & 0.612 & & 0.112 & 0.76 & \\
\hline
\end{tabular}

This table shows results of pooled, fixed (FE), and random effects (RE) estimations of the effect of ownership concentration on firm value. Panel A shows parametric results, while Panel B shows the parametric results for the control variables in the local-linear kernel-based semiparametric estimations.

The dependent variable is firm performance, measured by market-to-book value. Largest shareholder is the percentage shareholdings of the largest shareholder in the firm, taking into account business groups and voting blocks. Size is the log of total assets. Short and Long term debt, Financial fixed assets, Capital expenditures, and $\mathrm{R} \& \mathrm{D}$ are all normalized by total assets. Financial fixed assets represents investment in financial fixed assets. Robust standard errors in parentheses: *** $\mathrm{p}<0.01,{ }^{* *} \mathrm{p}<0.05,{ }^{*} \mathrm{p}<0.1$. 
Table 5: The effect of concentration on firm performance: coordination center firms.

\begin{tabular}{|c|c|c|c|c|c|c|}
\hline & \multicolumn{6}{|c|}{ Market-to-book value } \\
\hline & \multicolumn{3}{|c|}{$\begin{array}{l}\text { Firms affiliated to a coordination center } \\
\qquad \mathrm{N}=531\end{array}$} & \multicolumn{3}{|c|}{$\begin{array}{l}\text { Firms not affiliated to a coordination center } \\
\qquad \mathrm{N}=1145\end{array}$} \\
\hline & $\begin{array}{c}(1) \\
\text { Pooled }\end{array}$ & $\begin{array}{l}(2) \\
\mathrm{FE}\end{array}$ & $\begin{array}{l}(3) \\
\mathrm{RE}\end{array}$ & $\begin{array}{c}(4) \\
\text { Pooled }\end{array}$ & $\begin{array}{l}(5) \\
\mathrm{FE}\end{array}$ & $\begin{array}{l}(6) \\
\mathrm{RE}\end{array}$ \\
\hline \multicolumn{7}{|c|}{ Panel A: Parametric models } \\
\hline Largest shareholder & $\begin{array}{c}0.062 \\
(0.225)\end{array}$ & $\begin{array}{l}0.428^{*} \\
(0.232)\end{array}$ & $\begin{array}{c}0.331 \\
(0.216)\end{array}$ & $\begin{array}{c}-0.236^{*} \\
(0.129)\end{array}$ & $\begin{array}{c}0.487^{* * *} \\
(0.162)\end{array}$ & $\begin{array}{c}0.236 \\
(0.149)\end{array}$ \\
\hline Size & $\begin{array}{c}-0.102^{* * *} \\
(0.026)\end{array}$ & $\begin{array}{c}-0.439 * * * \\
(0.064)\end{array}$ & $\begin{array}{c}-0.247 * * * \\
(0.044)\end{array}$ & $\begin{array}{c}-0.037^{*} \\
(0.020)\end{array}$ & $\begin{array}{c}-0.308^{* * *} \\
(0.037)\end{array}$ & $\begin{array}{c}-0.204^{* * *} \\
(0.030)\end{array}$ \\
\hline Short term debt & $\begin{array}{c}-0.571^{* * *} \\
(0.184)\end{array}$ & $\begin{array}{c}-0.942^{* * *} \\
(0.235)\end{array}$ & $\begin{array}{c}-0.946^{* * *} \\
(0.222)\end{array}$ & $\begin{array}{l}-0.426 \\
(0.285)\end{array}$ & $\begin{array}{l}-0.002 \\
(0.128)\end{array}$ & $\begin{array}{l}-0.067 \\
(0.120)\end{array}$ \\
\hline Long term debt & $\begin{array}{c}-0.736^{* * *} \\
(0.168)\end{array}$ & $\begin{array}{c}-1.478^{* * *} \\
(0.250)\end{array}$ & $\begin{array}{c}-1.337 * * * \\
(0.230)\end{array}$ & $\begin{array}{c}-0.821^{* * * *} \\
(0.234)\end{array}$ & $\begin{array}{c}-0.886 * * * \\
(0.185)\end{array}$ & $\begin{array}{c}-0.797^{* * *} \\
(0.181)\end{array}$ \\
\hline Financial fixed assets & $\begin{array}{c}0.163 \\
(0.176)\end{array}$ & $\begin{array}{c}0.265 \\
(0.207)\end{array}$ & $\begin{array}{c}0.136 \\
(0.190)\end{array}$ & $\begin{array}{c}0.128 \\
(0.101)\end{array}$ & $\begin{array}{l}0.057 \\
(0.114)\end{array}$ & $\begin{array}{c}0.073 \\
(0.107)\end{array}$ \\
\hline Capital expenditures & $\begin{array}{l}3.776^{*} \\
(2.001)\end{array}$ & $\begin{array}{l}-0.230 \\
(1.276)\end{array}$ & $\begin{array}{l}-0.009 \\
(1.268)\end{array}$ & $\begin{array}{l}1.426^{* *} \\
(0.604)\end{array}$ & $\begin{array}{c}0.674^{* *} \\
(0.307)\end{array}$ & $\begin{array}{l}0.695^{* *} \\
(0.312)\end{array}$ \\
\hline$R \& D$ & $\begin{array}{c}19.172^{* * *} \\
(4.134)\end{array}$ & $\begin{array}{c}14.173^{* *} \\
(5.815)\end{array}$ & $\begin{array}{c}18.877^{* * * *} \\
(4.629)\end{array}$ & $\begin{array}{l}3.826^{*} \\
(1.990)\end{array}$ & $\begin{array}{c}3.699 \\
(3.084)\end{array}$ & $\begin{array}{c}1.649 \\
(1.796)\end{array}$ \\
\hline $\begin{array}{l}\text { Year dummies } \\
\text { R-squared }\end{array}$ & $\begin{array}{c}\text { Yes } \\
0.245\end{array}$ & $\begin{array}{c}\text { Yes } \\
0.377\end{array}$ & Yes & $\begin{array}{c}\text { Yes } \\
0.098\end{array}$ & $\begin{array}{c}\text { Yes } \\
0.245\end{array}$ & Yes \\
\hline \multicolumn{7}{|c|}{ Panel B: Parametric part of semiparametric models } \\
\hline Size & $\begin{array}{l}-0.042 \\
(0.032)\end{array}$ & $\begin{array}{c}-0.566^{* * *} \\
(0.078)\end{array}$ & $\begin{array}{c}-0.186^{* * *} \\
(0.064)\end{array}$ & $\begin{array}{c}-0.045^{* * *} \\
(0.014)\end{array}$ & $\begin{array}{c}-0.251^{* * *} \\
(0.039)\end{array}$ & $\begin{array}{c}-0.082^{* * *} \\
(0.028)\end{array}$ \\
\hline Short term debt & $\begin{array}{c}-0.638^{* * *} \\
(0.237)\end{array}$ & $\begin{array}{c}-1.119^{* * *} \\
(0.298)\end{array}$ & $\begin{array}{c}-0.869^{* *} \\
(0.367)\end{array}$ & $\begin{array}{c}-0.414^{* * *} \\
(0.117)\end{array}$ & $\begin{array}{l}-0.051 \\
(0.127)\end{array}$ & $\begin{array}{l}-0.184 \\
(0.158)\end{array}$ \\
\hline Long term debt & $\begin{array}{c}-1.68^{* * *} \\
(0.392)\end{array}$ & $\begin{array}{c}-1.976^{* * * *} \\
(0.386)\end{array}$ & $\begin{array}{c}-1.571^{* * *} \\
(0.523)\end{array}$ & $\begin{array}{c}-0.541^{* * *} \\
(0.149)\end{array}$ & $\begin{array}{c}-0.886^{* * *} \\
(0.167)\end{array}$ & $\begin{array}{c}-0.702^{* * *} \\
(0.213)\end{array}$ \\
\hline Financial fixed assets & $\begin{array}{l}-0.313^{*} \\
(0.186)\end{array}$ & $\begin{array}{l}-0.196 \\
(0.236)\end{array}$ & $\begin{array}{l}-0.261 \\
(0.293)\end{array}$ & $\begin{array}{c}0.403^{* * *} \\
(0.087)\end{array}$ & $\begin{array}{c}0.384^{* * *} \\
(0.112)\end{array}$ & $\begin{array}{l}0.353^{* *} \\
(0.138)\end{array}$ \\
\hline Capital expenditures & $\begin{array}{c}5.127^{* * *} \\
(1.518)\end{array}$ & $\begin{array}{l}0.187 \\
(1.23)\end{array}$ & $\begin{array}{c}2.051 \\
(1.806)\end{array}$ & $\begin{array}{c}1.258^{* * *} \\
(0.429)\end{array}$ & $\begin{array}{c}0.641^{* *} \\
(0.312)\end{array}$ & $\begin{array}{l}0.743 \\
(0.46)\end{array}$ \\
\hline $\mathrm{R} \& \mathrm{D}$ & $\begin{array}{c}18.511^{* * *} \\
(3.745)\end{array}$ & $\begin{array}{c}18.385^{* * * *} \\
(6.431)\end{array}$ & $\begin{array}{c}20.389^{* * *} \\
(7.733)\end{array}$ & $\begin{array}{l}5.89^{* * * *} \\
(1.514)\end{array}$ & $\begin{array}{l}1.595 \\
(3.032)\end{array}$ & $\begin{array}{l}3.462^{*} \\
(1.955)\end{array}$ \\
\hline $\begin{array}{l}\text { Year dummies } \\
\text { R-squared }\end{array}$ & $\begin{array}{c}\text { Yes } \\
0.229\end{array}$ & $\begin{array}{c}\text { Yes } \\
0.539\end{array}$ & Yes & $\begin{array}{l}\text { Yes } \\
0.14\end{array}$ & $\begin{array}{c}\text { Yes } \\
0.788\end{array}$ & Yes \\
\hline \multicolumn{7}{|c|}{$\begin{array}{l}\text { This table shows results of pooled, fixed (FE), and random effects (RE) estimations of the effect of ownership } \\
\text { concentration on firm value. Panel A shows parametric results, while Panel B shows the parametric results for the } \\
\text { control variables in the local-linear kernel-based semiparametric estimations. } \\
\text { The dependent variable is firm performance, measured by market-to-book value. Largest shareholder is the percentage } \\
\text { shareholdings of the largest shareholder in the firm, taking into account business groups and voting blocks. Size is } \\
\text { the log of total assets. Short and Long term debt, Financial fixed assets, Capital expenditures, and R\&D are all } \\
\text { normalized by total assets. Financial fixed assets represents investment in financial fixed assets. } \\
\text { Robust standard errors in parentheses: }{ }^{* * *} \mathrm{p}<0.01,{ }^{* *} \mathrm{p}<0.05,{ }^{*} \mathrm{p}<0.1 \text {. }\end{array}$} \\
\hline
\end{tabular}


Table 6: The effect of concentration on firm performance: whole sample and family firms, Return on Assets (RoA).

\begin{tabular}{|c|c|c|c|c|c|c|c|c|c|}
\hline & \multicolumn{9}{|c|}{ Return on Assets (RoA) } \\
\hline & \multicolumn{3}{|c|}{$\begin{array}{c}\text { Whole Sample } \\
\qquad \mathrm{N}=918\end{array}$} & \multicolumn{3}{|c|}{$\begin{array}{l}\text { Family firms } \\
\quad \mathrm{N}=367\end{array}$} & \multicolumn{3}{|c|}{$\begin{array}{l}\text { Non-family firms } \\
\qquad \mathrm{N}=551\end{array}$} \\
\hline & $\begin{array}{c}(1) \\
\text { Pooled }\end{array}$ & $\begin{array}{l}(2) \\
\mathrm{FE}\end{array}$ & $\begin{array}{l}(3) \\
\mathrm{RE}\end{array}$ & $\begin{array}{c}(4) \\
\text { Pooled }\end{array}$ & $\begin{array}{l}(5) \\
\mathrm{FE}\end{array}$ & $\begin{array}{l}(6) \\
\mathrm{RE}\end{array}$ & $\begin{array}{c}(7) \\
\text { Pooled }\end{array}$ & $\begin{array}{l}(8) \\
\mathrm{FE}\end{array}$ & $\begin{array}{l}(9) \\
\mathrm{RE}\end{array}$ \\
\hline \multicolumn{10}{|c|}{ Panel A: Parametric models } \\
\hline Largest shareholder & $\begin{array}{c}0.025 \\
(0.020)\end{array}$ & $\begin{array}{c}0.053 \\
(0.037)\end{array}$ & $\begin{array}{c}0.039 \\
(0.024)\end{array}$ & $\begin{array}{l}0.063^{*} \\
(0.034)\end{array}$ & $\begin{array}{l}-0.035 \\
(0.063)\end{array}$ & $\begin{array}{c}0.034 \\
(0.042)\end{array}$ & $\begin{array}{l}-0.006 \\
(0.025)\end{array}$ & $\begin{array}{l}0.078^{*} \\
(0.046)\end{array}$ & $\begin{array}{c}0.023 \\
(0.028)\end{array}$ \\
\hline Size & $\begin{array}{l}0.020^{* * * *} \\
(0.002)\end{array}$ & $\begin{array}{c}0.026 * * * \\
(0.010)\end{array}$ & $\begin{array}{c}0.024^{* * *} \\
(0.004)\end{array}$ & $\begin{array}{c}0.014^{* * *} \\
(0.004)\end{array}$ & $\begin{array}{c}0.007 \\
(0.013)\end{array}$ & $\begin{array}{l}0.011^{*} \\
(0.006)\end{array}$ & $\begin{array}{c}0.022^{* * *} \\
(0.003)\end{array}$ & $\begin{array}{c}0.038^{* *} \\
(0.015)\end{array}$ & $\begin{array}{c}0.027 * * * \\
(0.004)\end{array}$ \\
\hline Short term debt & $\begin{array}{l}-0.110^{* * *} \\
(0.020)\end{array}$ & $\begin{array}{l}-0.198^{* * *} \\
(0.033)\end{array}$ & $\begin{array}{l}-0.148^{* * * *} \\
(0.026)\end{array}$ & $\begin{array}{l}-0.091 * * * \\
(0.031)\end{array}$ & $\begin{array}{l}-0.160 * * * \\
(0.047)\end{array}$ & $\begin{array}{l}-0.116^{* * *} \\
(0.037)\end{array}$ & $\begin{array}{l}-0.139 * * * \\
\quad(0.027)\end{array}$ & $\begin{array}{l}-0.219^{* * *} \\
(0.049)\end{array}$ & $\begin{array}{c}-0.162^{* * *} \\
(0.035)\end{array}$ \\
\hline Long term debt & $\begin{array}{l}-0.178^{* * *} \\
(0.033)\end{array}$ & $\begin{array}{l}-0.183^{* * *} \\
(0.038)\end{array}$ & $\begin{array}{l}-0.187^{* * * *} \\
(0.030)\end{array}$ & $\begin{array}{l}-0.135^{* * *} \\
(0.037)\end{array}$ & $\begin{array}{l}-0.085 \\
(0.062)\end{array}$ & $\begin{array}{l}-0.094^{*} \\
(0.051)\end{array}$ & $\begin{array}{l}-0.199^{* * *} \\
(0.040)\end{array}$ & $\begin{array}{l}-0.187^{* * *} \\
(0.051)\end{array}$ & $\begin{array}{l}-0.211^{* * *} \\
\quad(0.037)\end{array}$ \\
\hline Financial fixed assets & $\begin{array}{l}-0.054^{* * *} \\
(0.013)\end{array}$ & $\begin{array}{l}-0.110^{* * *} \\
(0.027)\end{array}$ & $\begin{array}{l}-0.071 * * * \\
(0.018)\end{array}$ & $\begin{array}{c}-0.051^{* *} \\
(0.025)\end{array}$ & $\begin{array}{l}-0.024 \\
(0.039)\end{array}$ & $\begin{array}{l}-0.034 \\
(0.028)\end{array}$ & $\begin{array}{l}-0.055^{* * *} \\
(0.015)\end{array}$ & $\begin{array}{l}-0.162^{* * *} \\
(0.039)\end{array}$ & $\begin{array}{c}-0.076^{* * *} \\
(0.023)\end{array}$ \\
\hline Capital expenditures & $\begin{array}{c}0.097 \\
(0.076)\end{array}$ & $\begin{array}{c}0.089 \\
(0.153)\end{array}$ & $\begin{array}{c}0.071 \\
(0.084)\end{array}$ & $\begin{array}{c}0.302^{* *} \\
(0.137)\end{array}$ & $\begin{array}{c}0.080 \\
(0.212)\end{array}$ & $\begin{array}{c}0.169 \\
(0.194)\end{array}$ & $\begin{array}{c}0.034 \\
(0.046)\end{array}$ & $\begin{array}{c}0.049 \\
(0.219)\end{array}$ & $\begin{array}{c}0.047 \\
(0.095)\end{array}$ \\
\hline $\mathrm{R} \& \mathrm{D}$ & $\begin{array}{l}-0.506 \\
(0.389)\end{array}$ & $\begin{array}{c}0.026 \\
(0.541)\end{array}$ & $\begin{array}{l}-0.437 \\
(0.393)\end{array}$ & $\begin{array}{c}0.719^{* *} \\
(0.295)\end{array}$ & $\begin{array}{c}0.367 \\
(0.903)\end{array}$ & $\begin{array}{c}0.577 \\
(0.670)\end{array}$ & $\begin{array}{c}-1.027^{* *} \\
(0.498)\end{array}$ & $\begin{array}{l}-0.220 \\
(0.690)\end{array}$ & $\begin{array}{l}-0.852^{*} \\
(0.483)\end{array}$ \\
\hline $\begin{array}{l}\text { Year dummies } \\
\text { R-squared }\end{array}$ & $\begin{array}{l}\text { Yes } \\
0.187\end{array}$ & $\begin{array}{c}\text { Yes } \\
0.146\end{array}$ & Yes & $\begin{array}{c}\text { Yes } \\
0.141\end{array}$ & $\begin{array}{l}\text { Yes } \\
0.087\end{array}$ & Yes & $\begin{array}{c}\text { Yes } \\
0.249\end{array}$ & $\begin{array}{c}\text { Yes } \\
0.206\end{array}$ & Yes \\
\hline Size & $\begin{array}{c}0.019^{* * *} \\
(0.002)\end{array}$ & $\begin{array}{c}0.028^{* * *} \\
(0.009)\end{array}$ & $\begin{array}{c}0.024^{* * *} \\
(0.004)\end{array}$ & $\begin{array}{c}0.021^{* * *} \\
(0.004)\end{array}$ & $\begin{array}{c}0.048 * * * \\
(0.013)\end{array}$ & $\begin{array}{c}0.023^{* * *} \\
(0.006)\end{array}$ & $\begin{array}{c}0.02 * * * \\
(0.003)\end{array}$ & $\begin{array}{l}0.021^{*} \\
(0.011)\end{array}$ & $\begin{array}{c}0.024^{* * * *} \\
(0.005)\end{array}$ \\
\hline Short term debt & $\begin{array}{c}-0.083^{* * * *} \\
(0.019)\end{array}$ & $\begin{array}{c}-0.205^{* * * *} \\
(0.031)\end{array}$ & $\begin{array}{c}-0.108^{* * * *} \\
(0.025)\end{array}$ & $\begin{array}{c}-0.121^{* * *} \\
(0.032)\end{array}$ & $\begin{array}{c}-0.271^{* * *} \\
(0.044)\end{array}$ & $\begin{array}{c}-0.172^{* * *} \\
(0.039)\end{array}$ & $\begin{array}{c}-0.064^{* * * *} \\
(0.024)\end{array}$ & $\begin{array}{c}-0.183^{* * * *} \\
(0.04)\end{array}$ & $\begin{array}{c}-0.077^{* *} \\
(0.031)\end{array}$ \\
\hline Long term debt & $\begin{array}{c}-0.153^{* * *} \\
(0.025)\end{array}$ & $\begin{array}{c}-0.18^{* * *} \\
(0.037)\end{array}$ & $\begin{array}{c}-0.159^{* * *} \\
(0.032)\end{array}$ & $\begin{array}{c}-0.191^{* * *} \\
(0.04)\end{array}$ & $\begin{array}{c}-0.205^{* * *} \\
(0.053)\end{array}$ & $\begin{array}{c}-0.202^{* * *} \\
(0.047)\end{array}$ & $\begin{array}{c}-0.145^{* * *} \\
(0.032)\end{array}$ & $\begin{array}{c}-0.188^{* * *} \\
(0.046)\end{array}$ & $\begin{array}{c}-0.15^{* * *} \\
(0.04)\end{array}$ \\
\hline Financial fixed assets & $\begin{array}{c}-0.048^{* * *} \\
(0.013)\end{array}$ & $\begin{array}{c}-0.092^{* * *} \\
(0.025)\end{array}$ & $\begin{array}{c}-0.064^{* * *} \\
(0.019)\end{array}$ & $\begin{array}{c}-0.047 \\
(0.03)\end{array}$ & $\begin{array}{c}-0.153^{* * *} \\
(0.039)\end{array}$ & $\begin{array}{c}-0.077^{* *} \\
(0.036)\end{array}$ & $\begin{array}{c}-0.044^{* * *} \\
(0.016)\end{array}$ & $\begin{array}{c}-0.083^{* * *} \\
(0.031)\end{array}$ & $\begin{array}{c}-0.059^{* * *} \\
(0.022)\end{array}$ \\
\hline Capital expenditures & $\begin{array}{c}0.071 \\
(0.081)\end{array}$ & $\begin{array}{c}0.042 \\
(0.147)\end{array}$ & $\begin{array}{c}0.053 \\
(0.092)\end{array}$ & $\begin{array}{c}-0.089 \\
(0.295)\end{array}$ & $\begin{array}{l}-0.293 \\
(0.273)\end{array}$ & $\begin{array}{c}-0.2 \\
(0.31)\end{array}$ & $\begin{array}{c}0.058 \\
(0.088)\end{array}$ & $\begin{array}{c}0.128 \\
(0.173)\end{array}$ & $\begin{array}{c}0.058 \\
(0.099)\end{array}$ \\
\hline $\mathrm{R} \& \mathrm{D}$ & $\begin{array}{c}-0.536^{*} \\
(0.3)\end{array}$ & $\begin{array}{c}0.06 \\
(0.561)\end{array}$ & $\begin{array}{l}-0.528 \\
(0.437)\end{array}$ & $\begin{array}{l}0.96^{* *} \\
(0.423)\end{array}$ & $\begin{array}{l}0.762 \\
(0.88)\end{array}$ & $\begin{array}{c}0.798 \\
(0.598)\end{array}$ & $\begin{array}{c}-1.385^{* * *} \\
(0.419)\end{array}$ & $\begin{array}{l}-0.107 \\
(0.689)\end{array}$ & $\begin{array}{l}-1.006^{*} \\
(0.557)\end{array}$ \\
\hline Year dummies & Yes & Yes & Yes & Yes & Yes & Yes & Yes & Yes & Yes \\
\hline R-squared & 0.273 & 0.723 & & 0.37 & 0.523 & & 0.288 & 0.759 & \\
\hline
\end{tabular}

This table shows results of pooled, fixed (FE), and random effects (RE) estimations of the effect of ownership concentration on firm value. Panel A shows parametric results, while Panel B shows the parametric results for the control variables in the local-linear kernel-based semiparametric estimations.

The dependent variable is firm performance, measured by return over assets (RoA). Largest shareholder is the percentage shareholdings of the largest shareholder in the firm, taking into account business groups and voting blocks. Size is the log of total assets. Short and Long term debt, Financial fixed assets, Capital expenditures, and R\&D are all normalized by total assets. Financial fixed assets represents investment in financial fixed assets.

Robust standard errors in parentheses: ${ }^{* * *} \mathrm{p}<0.01,{ }^{* *} \mathrm{p}<0.05,{ }^{*} \mathrm{p}<0.1$. 
Table 7: The effect of concentration on firm performance, controlling for the effect of the second largest shareholder: whole sample and family firms.

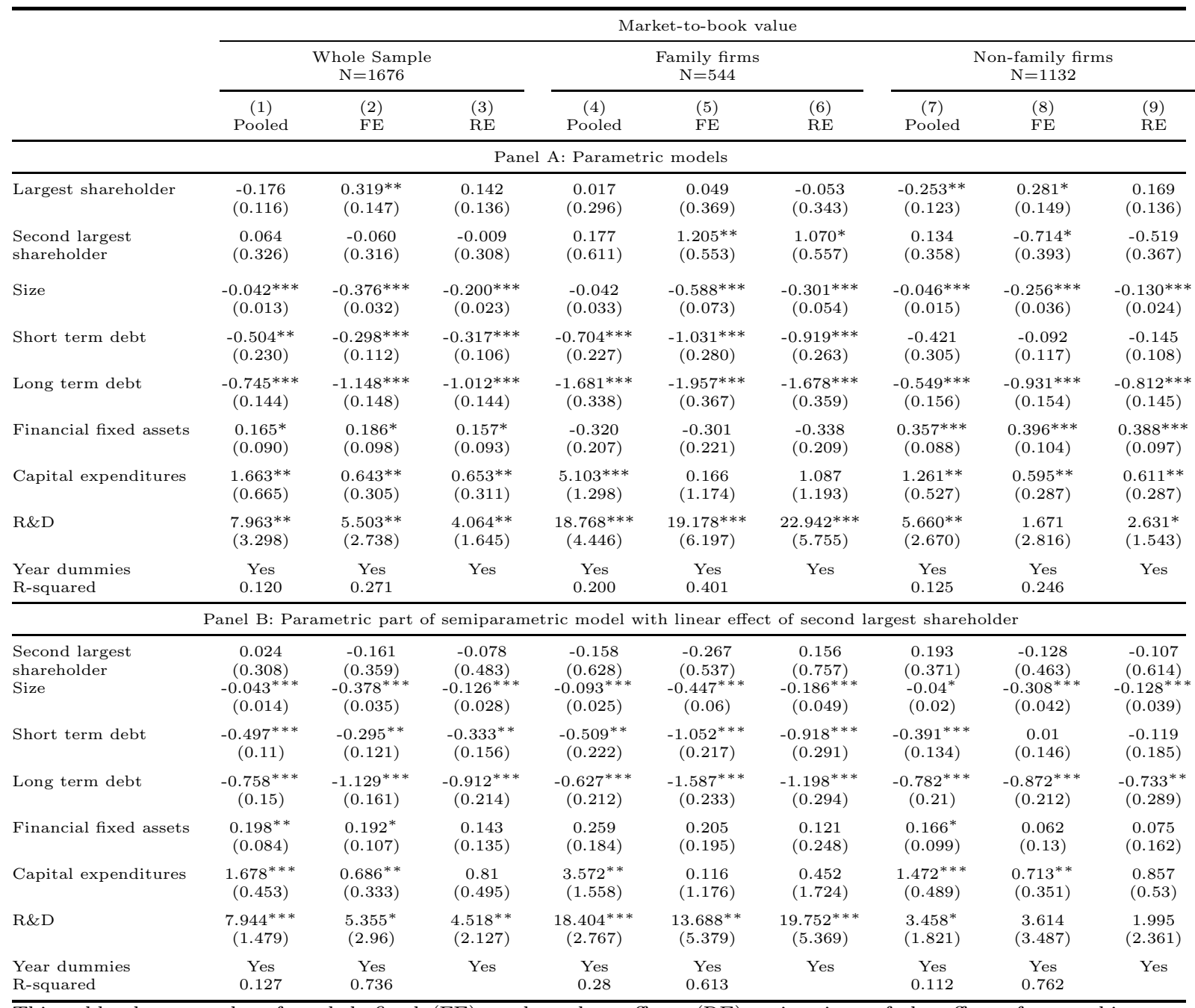

This table shows results of pooled, fixed (FE), and random effects (RE) estimations of the effect of ownership concentration on firm value. Panel A shows parametric results, while Panel B shows the parametric results for the control variables in the local-linear kernel-based semiparametric estimations.

The dependent variable is firm performance, measured by market-to-book value. Largest shareholder is the percentage shareholdings of the largest shareholder in the firm, taking into account business groups and voting blocks. Second largest shareholder is the percentage shareholdings of the second largest shareholder (whenever present, otherwise zero). Size is the log of total assets. Short and Long term debt, Financial fixed assets, Capital expenditures, and R\&D are all normalized by total assets. Financial fixed assets represents investment in financial fixed assets.

Robust standard errors in parentheses: *** $\mathrm{p}<0.01,{ }^{*} * \mathrm{p}<0.05{ }^{*} \mathrm{p}<0.1$. 

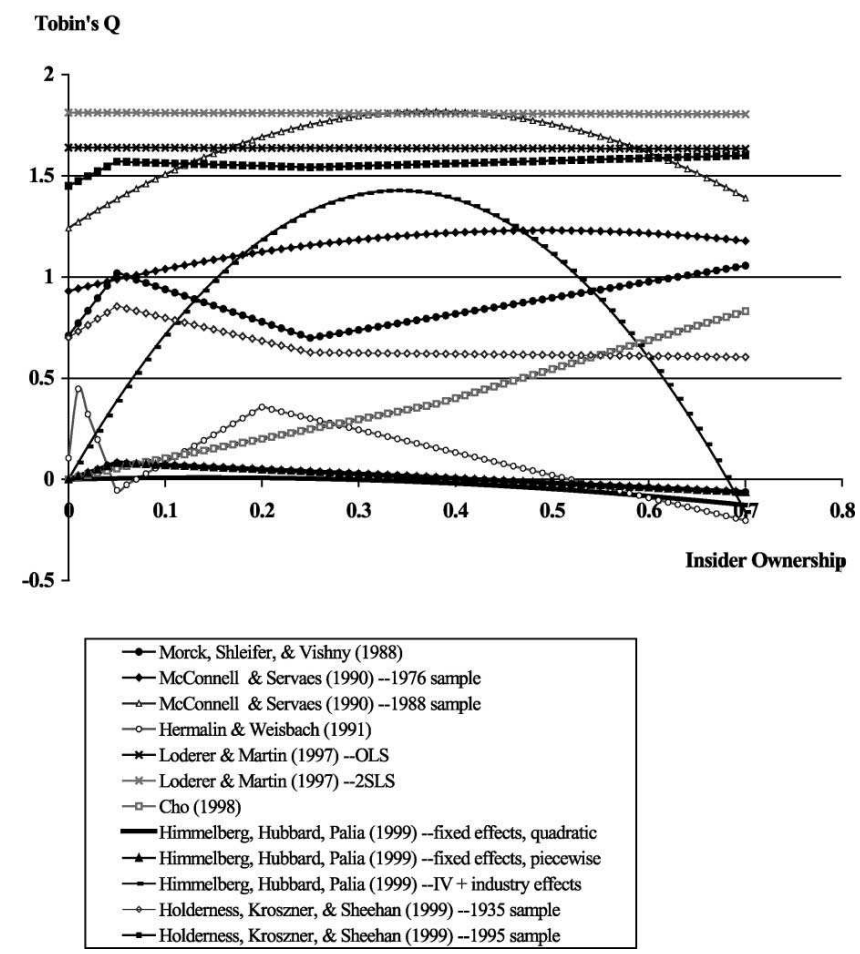

Figure 1: Relation between managerial ownership and firm performance found in the literature.

This figure from Demsetz and Villalonga, 2001, "Ownership Structure and Corporate Performance", Journal of Corporate Finance, 7, 209-233. illustrates the controversial relation between between managerial ownership and firm performance, measured by market-to-book value. 


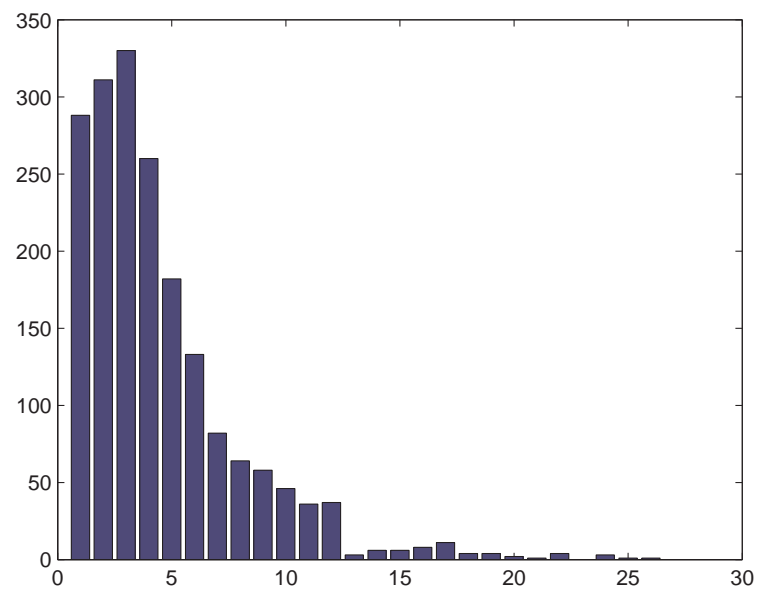

Figure 2: Distribution of the number of declared shareholders in a firm

This figure shows the distribution of all single shareholders in a firm, without accounting for their size (in terms of firm year observations). 

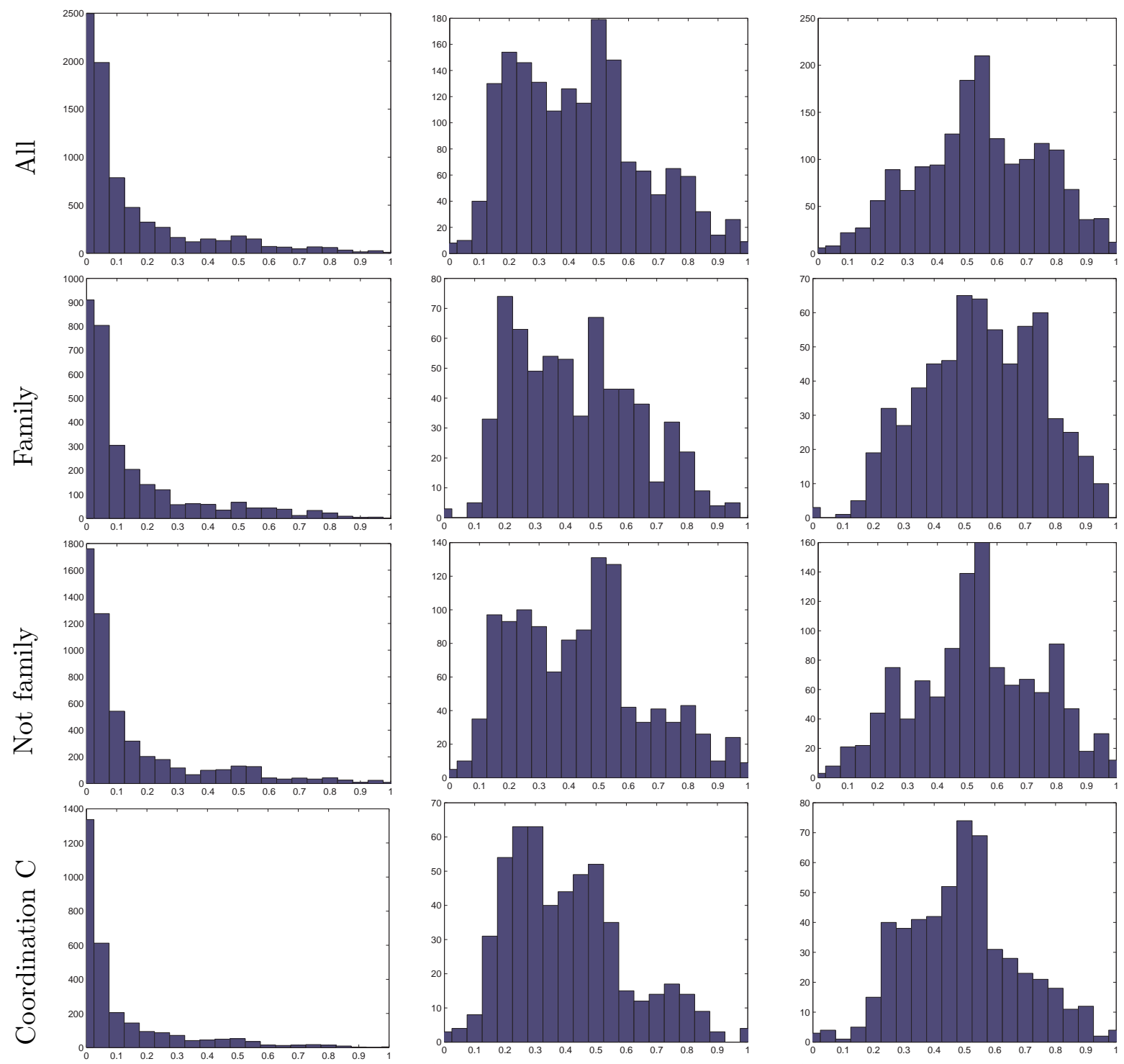

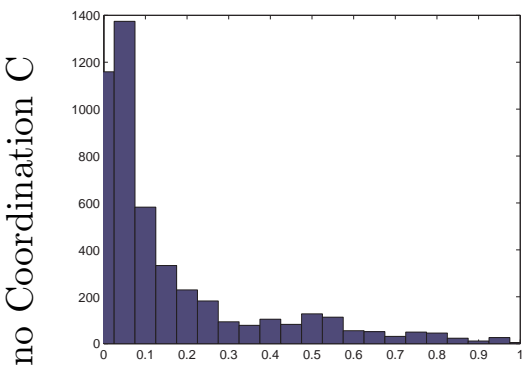

(a) Shareholders taken individually (single shareholders)

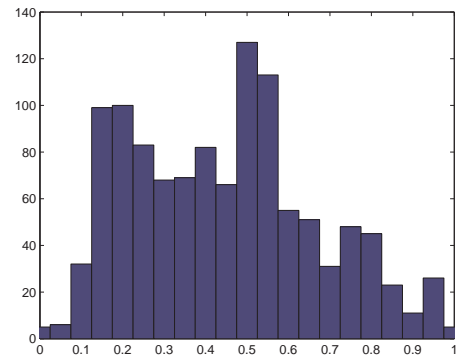

(b) Largest shareholder (without considering voting blocks and business groups)
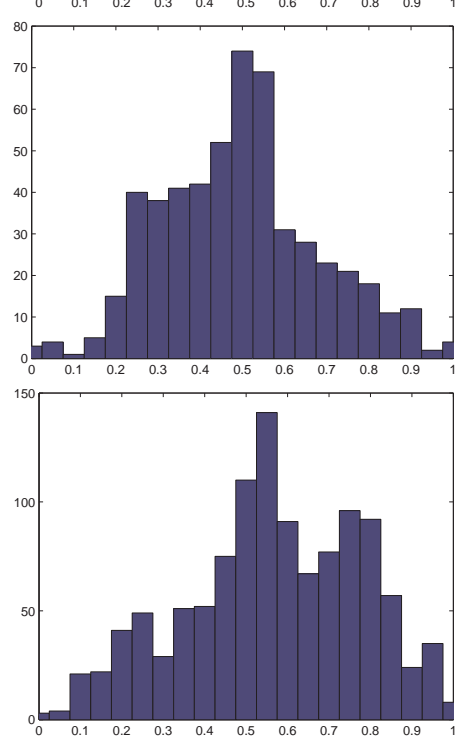

(c) Largest shareholder (when considering voting blocks and business groups)

Figure 3: Distribution of the share ownership of the first largest shareholders This figure shows the distribution of shareholders in various settings. The rows contain: (1) all firms, (2) family firms, (3) nonfamily firms, (4) firms affiliated to a coordination center, and (5) firms not affiliated to a coordination center. The columns contain: (a) distribution of individual declared shareholders (single sharebßglers), (b) distribution of largest shareholder (without taking into account business groups and voting blocks), (c) distribution of largest shareholder (taking into account business groups and voting blocks). 


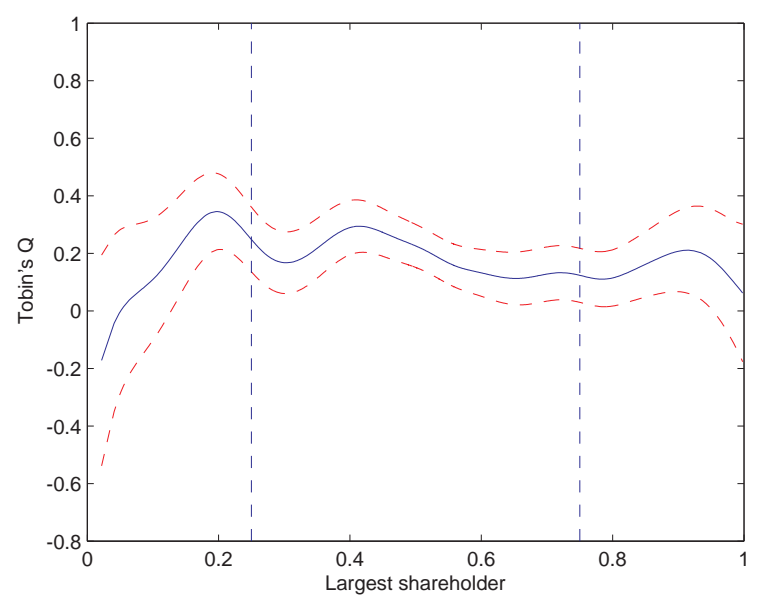

(a) Pooled estimation

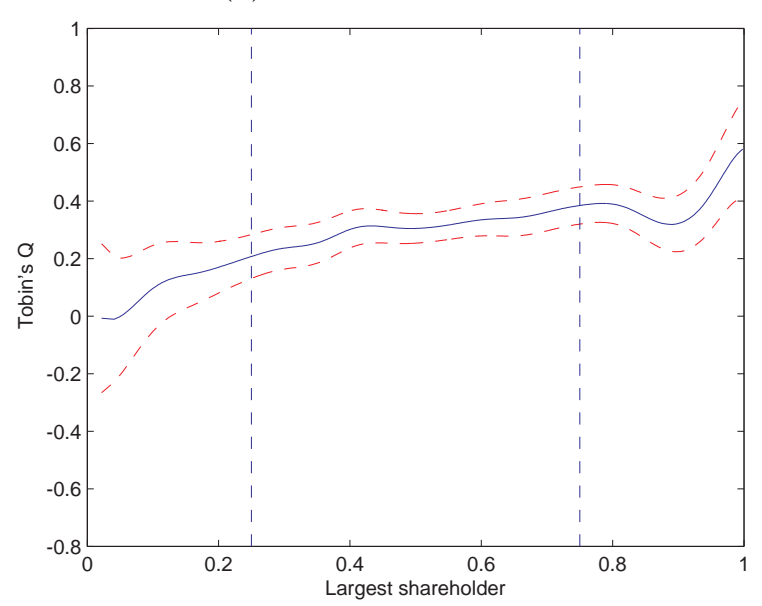

(c) Fixed effects estimation

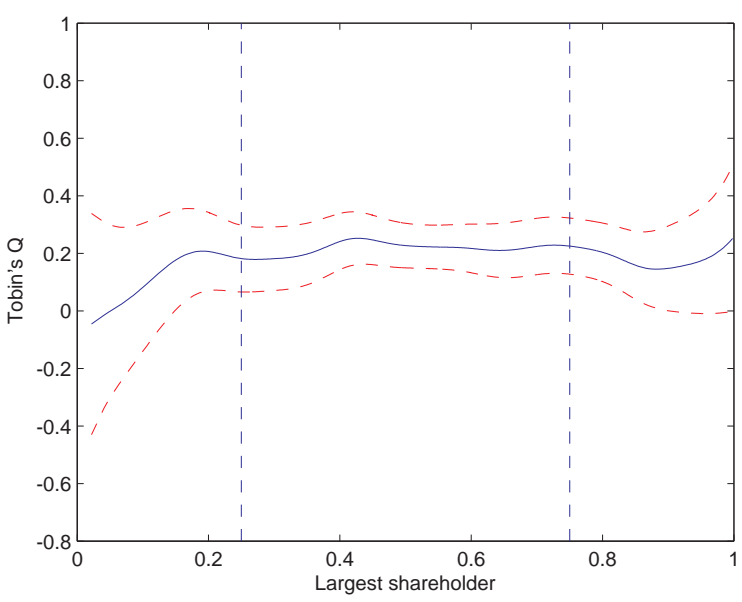

(b) Random effects estimation 


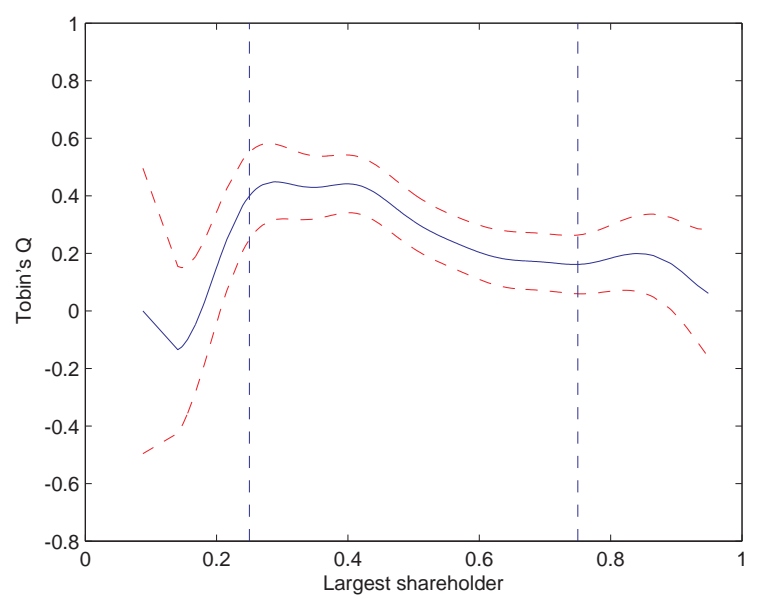

(a) Family firms

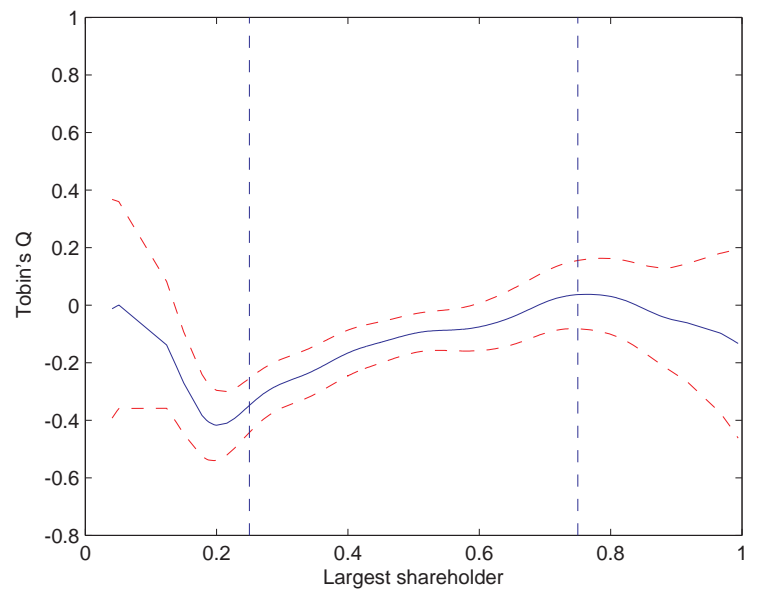

(c) Coordination Center

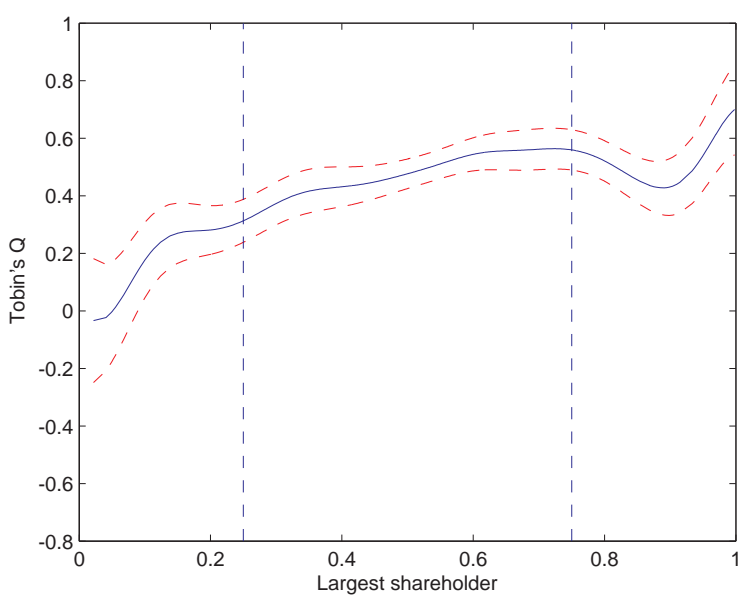

(b) Non-family firms

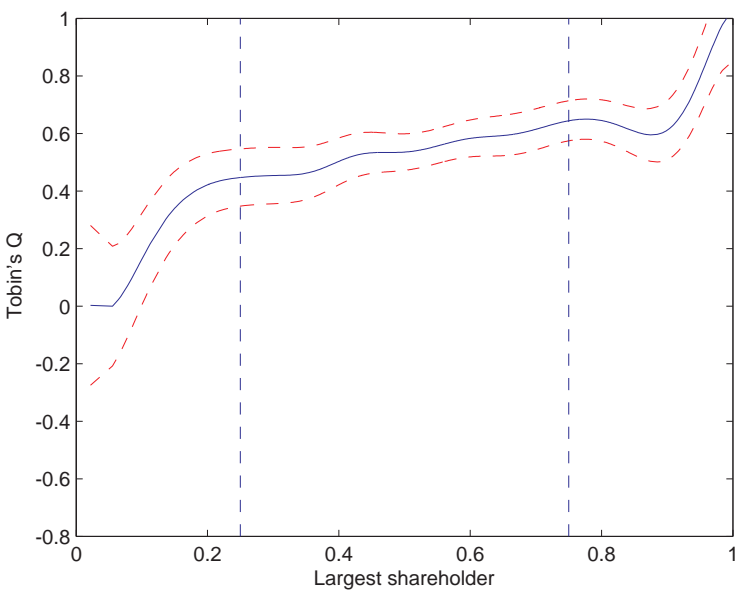

(d) No Coordination Center

Figure 5: Effect of the largest shareholder on firm performance for various subsamples.

This figure shows the effect of the largest shareholder on firm performance for various subsamples of (a) family and (b) non-family firms, as well as firms (c) with an affiliation to a business center, and (d) without such an affiliation. The estimates are based on the semiparametric fixed effect panel estimation, where the effect of , as well as year dummies, have ben taken into account linearly. The solid blue line in the middle is the estimate, while the upper and lower (dashed red) lines are the $95 \%$ confidence intervals. The figures contain vertical dotted lines at $25 \%$ and $75 \%$ of ownership, which correspond respectively to the threshold that, under certain circumstances, allows a shareholder to benefit from a tax exemption on dividends, and to modify the statutes of the firm. 

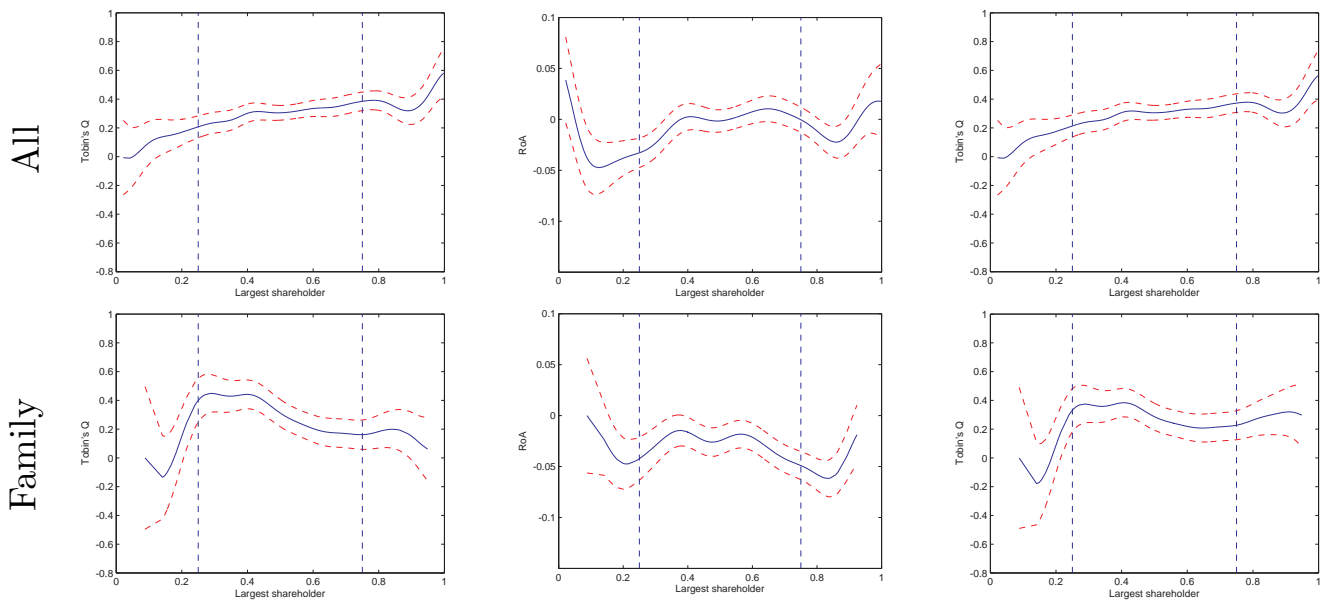

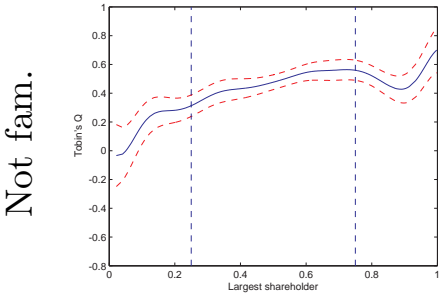

(a) Largest shareholder and market-to-book value (base results)

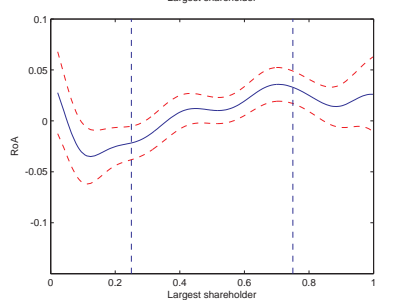

(b) Largest shareholder and RoA (reduced sample)

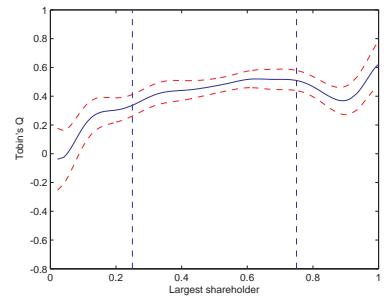

(c) Largest shareholder and market-to-book value (when controlling for the second shareholder)

Figure 6: Robustness checks

This figure shows various robustness checks. The rows contain results for : (1) all firms, (2) family firms, and (3) non-family firms. The columns contain, for the fixed effect semiparametric estimations, the nonparametric effect of : (a) the largest shareholder on market-to-book value (the base results, reproduced from Figures 4 and 5 for the sake of comparison), (b) the largest shareholder on return on assets (RoA), and (c) the largest shareholder on market-to-book value, when controlling for the second shareholder in the linear part of the model. The figures contain vertical dotted lines at $25 \%$ and $75 \%$ of ownership, which correspond respectively to the threshold that, under certain circumstances, allows a shareholder to benefit from a tax exemption on dividends, and to modify the statutes of the firm. 


\section{Appendices}

\section{A Disclosure law requirements}

The 1989 disclosure law makes notification to the Banking Commission mandatory for all shareholding of 5 percent or multiples thereof. The notification threshold may be as low as 3 percent if the company writes this into its statutes. However, there are exceptions where shareholdings below the 5 percent (or 3 percent) threshold lead to notification:

1. This may occur if the owners previously had an ownership of 5 percent or more, and reduced it to below 5 percent.

2. The notification takes into account stocks and warrants. For example, if the investor holds 1 percent in equity and 4 percent in warrants, he must notify the company.

3. When a shareholder leaves a voting pact, he/she is required to register this change.

The disclosure law applies directly to the owners of the voting rights, as well as to those investors who control voting rights indirectly via a pyramidal structure of intermediate companies. Investors are required to reveal whether they are affiliated to a group of companies or whether they act in concert with other investors.

Share ownership in Belgian listed firms can be organized in one of the three following ways.

1. Direct stakes: holdings of independent shareholders, either moral or physical persons.

2. Group blocks: stakes of companies that are part of a business group that is subject to consolidation rules under Belgian law.

3. Voting blocks: composed of direct stakes and/or group blocks. A voting block is a voting coalition, where shareholders declare that they act in unison together. 


\section{B Semiparametric panel estimation}

In this Appendix, we provide further details and discussion of the semiparametric pooled, random and fixed effect local-linear kernel-based estimation procedure that we use in the paper. We are interested in estimating the following partially linear panel specification:

$$
Y_{i t}=\theta\left(Z_{i t}\right)+X_{i t} \beta+\mu_{i}+\varepsilon_{i t},
$$

where $Y_{i t}$ is firm performance, $Z_{i t}$ is ownership, whose effect on performance is given by a function $\theta($.$) , and X_{i t}$ are control variables, whose effect on performance is linear. We make different assumptions on the error term $\epsilon_{i t}$.

\section{B.1 Random effects and pooled estimation}

We first analyze the random effects case when $\epsilon_{i t}=\mu_{i}+\varepsilon_{i t}$ and $\varepsilon_{i t}$ is assumed to be homoscedastic with variance $\sigma_{\varepsilon}^{2}$, uncorrelated over time, and independent of the timeinvariant firm-specific zero mean homoscedastic random term $\mu_{i}$, whose variance is $\sigma_{\mu}^{2}$. The variance covariance matrix for cluster $i$ takes the form $V_{i}=\sigma_{\varepsilon}^{2} I_{T_{i}}+\sigma_{\mu}^{2} e_{T_{i}} e_{T_{i}}^{\prime}$, with

inverse $V_{i}^{-1}=\sigma_{\varepsilon}^{-2}\left(I_{T_{i}}-\frac{\sigma_{\mu}^{2}}{\sigma_{\mu}^{2}+T_{i} \sigma_{\varepsilon}^{2}} e_{T_{i}} e_{T_{i}}^{\prime}\right)$ and diagonal $\operatorname{diag}\left(V_{i}^{-1}\right)=\left(1-\frac{\sigma_{\mu}^{2}}{\sigma_{\mu}^{2}+T_{i} \sigma_{\varepsilon}^{2}}\right) I_{T_{i}-1}$, where $I_{n}$ is the identity matrix of dimension $n$, and $e_{n}$ is an $n$-dimensional column vector of ones. Lin and Carroll (2000) suggest that in the case of a kernel-based nonparametric local polynomial regression with clustered data, unlike in the parametric case, it is best to ignore the cluster correlation. Lin and Carroll (2001) consider semiparametric regression in the clustered case, where the variable in the nonparametric part varies only at the cluster level, but is the same for all individuals within the cluster. The results are very different if the nonparametric variable varies at observation level. Wang (2003) is the first to show how to incorporate cluster correlation into the nonparametric estimation to achieve higher efficiency. We present the estimation procedure proposed by Wang, Carroll, and Lin (2005) for the efficient estimation of a semiparametric regression with cluster level random effects.

The objective function of the semiparametric local linear kernel random effect estimator is a kernel-smoothed version of 


$$
L_{i}=-\frac{1}{2}\left(Y_{i}-\theta_{i}-X_{i} \beta_{R}\right)^{\prime} V_{i}^{-1}\left(Y_{i}-\theta_{i}-X_{i} \beta_{R}\right),
$$

where, at the level of cluster $i, L_{i}$ is the loglikelihood, $Y_{i}=\left(Y_{i 1}, \ldots, Y_{i, T_{i}}\right)$ the dependent variable, $X_{i}=\left(X_{i 1}, \ldots, X_{i, T_{i}}\right)$ the explanatory variables with a linear effect and associated parameter $\beta_{R}$, and $\theta_{R}=\left(\theta_{1}, \ldots, \theta_{n}\right)$ with $\theta_{i}=\left(\theta_{i 1}, \ldots, \theta_{i, T_{i}}\right)$ is the nonparametric function estimate, which can be estimated using the following algorithm, given in Wang, Carroll, and Lin (2005):

Step I: Given an initial value of $\beta_{R}$, solve the first order condition

$$
\sum_{i=1}^{n} \sum_{t=1}^{T_{i}} K_{h}\left(Z_{i t}-z\right) G_{i t}^{\prime}(z) V_{i}^{-1}\left[Y_{i}-\mu^{*}\right]=0,
$$

where $G_{i t}(z)$ is a $T_{i}$ by $(q+1)$ matrix of zeros except that for the local linear estimator, the $t$-th row is $g_{i t}(z, h)^{\prime}=\left[1,\left\{\left(Z_{i t}-z\right) / h\right\}^{\prime}\right]$, the $s$-th element of $\mu^{*}$ is $X_{i s}^{\prime} \beta_{R}+\mathbb{1}_{\{s=t\}}\left\{\hat{\alpha}_{0}+\right.$ $\left.\hat{\alpha}_{1}\left(Z_{i t}-z\right) / h\right\}+\mathbb{1}_{\{s \neq t\}} \tilde{\theta}_{R}\left(Z, \beta_{R}\right)$, where $\tilde{\theta}_{R}$ is the current estimate of $\theta_{R}$. With $q$ variables in the nonparametric part of the model, the estimation uses a product kernel $K_{h}(v)=$ $\prod_{j=1}^{q} h_{j}^{-1} k\left(v_{h} / h_{j}\right)$, where $k($.$) is a univariate kernel, and h=\left(h_{1}, \ldots, h_{q}\right)$ is the vector of bandwidths. We use the Gaussian kernel, and thus the bandwidth is simply the standard deviation of the Gaussian kernel. Given the current estimate of $\tilde{\theta}_{R}$, the updated estimate is given as $\hat{\theta}_{R}\left(z, \beta_{R}\right)=\hat{\alpha}_{0}\left(z, \beta_{R}\right)$.

Step II: The coefficient $\beta_{R}$ of the parametric part of the model is estimated by a profile likelihood approach. In Step I, we computed the optimal nonparametric function $\theta_{R}$ for any given value of $\beta_{R}$. In Step II, we have to find the optimal $\beta_{R}$ that takes into account both the direct effect of $\beta_{R}$ on the criterion and also its indirect effect, via $\theta_{R}, \frac{\partial \hat{\theta}_{R}}{\partial \beta_{R}}$. Thus, given an estimate of $\frac{\partial \hat{\theta}_{R}}{\partial \beta_{R}}, \beta_{R}$ can be found by solving the following optimization problem:

$$
\min _{\beta_{R}} \sum_{i=1}^{n}\left(Y_{i}-\hat{\theta}_{R}-X_{i} \beta_{R}\right)^{\prime} V_{i}^{-1}\left(Y_{i}-\hat{\theta}_{R}-X_{i} \beta_{R}\right) .
$$

The method consists in iterating between steps I and II until convergence.

Pooled estimation can be carried out by using the random effects methodology with $V_{i}=\sigma_{\varepsilon}^{2} I_{T_{i}}$. 
The variance of the estimator of the nonparametric part of the model is as follows, (see e.g. Wang 2003):

$$
\operatorname{Var}\left[\hat{\theta}_{R}(z)-\theta_{R}(z)\right]=\frac{\kappa}{\left(n h_{1} \ldots h_{q}\right)} \sum_{i=1}^{n} \frac{1}{\sigma_{\varepsilon}^{2}}\left(1-\frac{\sigma_{\mu}^{2}}{\sigma_{\varepsilon}^{2}+T_{i} \sigma_{\mu}^{2}}\right) \sum_{t=1}^{T_{i}} K_{h}\left(Z_{i t}-z\right) .
$$

\section{B.2 Fixed effects}

For the fixed effects estimation, which is generally considered the more relevant in economics, given concerns of endogeneity, the literature is more scant than for the random effect. Su and Ullah (2006) consider a partially linear fixed effects model based on a profile likelihood. Li and Stengos (1996) propose a method to estimate a semiparametric panel with endogenous regressors in an instrumental variable context. We rely on the recent methodology of Henderson, Carroll, and Li (2008), which generalizes the Wang, Carroll, and Lin (2005) approach to the fixed effects case. This method has been applied recently by Zhou and Li (2011) in the context of the relation between inequality and development.

Henderson, Carroll, and Li (2008), whose presentation we follow in this subsection, propose to estimate the nonparametric model along the lines of Wang (2003) and Lin and Carroll (2006). The clustered nature of the data somewhat complicates the estimation, which proceeds as follows. The fixed effect is handled by first differencing the data:

$$
\tilde{Y}_{i t} \equiv Y_{i t}-Y_{i 1}=\theta_{F}\left(Z_{i t}\right)-\theta_{F}\left(Z_{i 1}\right)+\tilde{X}_{i t}^{\prime} \beta_{F}+\epsilon_{i t}-\epsilon_{i 1}
$$

where $\tilde{X}_{i t} \equiv X_{i t}-X_{i 1}$. We further collect observations over time for firm $i$, in vector $\tilde{Y}_{i}=\left(\tilde{Y}_{i 2}, \ldots, \tilde{Y}_{i T_{i}}\right)$ for the dependent variable, in vector $\theta_{i}=\left(\theta_{i, 2}, \ldots, \theta_{i, T_{i}}\right)$ for the nonparametric part, and in matrix $\tilde{X}_{i}=\left(\tilde{X}_{i 2}, \ldots, \tilde{X}_{i T_{i}}\right)$ for the linear regressors and we denote $v_{i t} \equiv \epsilon_{i t}-\epsilon_{i 1}$. First differencing introduces structure into the $\left(T_{i}-1\right)$ dimensional variance covariance matrix $\Sigma_{i}$, which the estimation method takes into account: $\Sigma_{i}=\sigma_{v}^{2}\left(I_{T_{i}-1}+e_{T_{i}-1} e_{T_{i}-1}^{\prime}\right)$, and thus $\Sigma_{i}^{-1}=\sigma_{v}^{-2}\left(I_{T_{i}-1}-e_{T_{i}-1} e_{T_{i}-1}^{\prime} / T_{i}\right)$. In the pure nonparametric case $\left(\right.$ no $\left.X_{i t} \mathrm{~s}\right)$, the parameters are estimated by maximizing a kernel-weighted version of the following criterion: 


$$
L_{i t}=-\frac{1}{2}\left(\tilde{Y}_{i}-\theta_{i}+\theta_{i 1} e_{T_{i}-1}\right)^{\prime} \Sigma_{i}^{-1}\left(\tilde{Y}_{i}-\theta_{i}+\theta_{i 1} e_{T_{i}-1}\right)
$$

for $i=1,2, \ldots, n$, where, in the presence of other subscripts in $\theta$, we drop the $F$ subscript to ease notation. Denoting the first and second order derivatives of the likelihood $L_{i, t \theta}=\frac{\partial L_{i t}}{\partial \theta_{i t}}$ and $L_{i, s t \theta}=\frac{\partial^{2} L_{i t}}{\partial \theta_{i t} \partial \theta_{i s}}$, we have:

$$
\begin{aligned}
L_{i, 1 \theta} & =-e_{T_{i}-1}^{T} \Sigma_{i}^{-1}\left(\tilde{Y}_{i}-\theta_{i}+\theta_{i 1} e_{T_{i}-1}\right), \\
L_{i, t \theta} & =-c_{t-1}^{\prime} \Sigma_{i}^{-1}\left(\tilde{Y}_{i}-\theta_{i}+\theta_{i 1} e_{T_{i}-1}\right) \quad \text { for } t \geq 2,
\end{aligned}
$$

where $c_{t-1}$ is a $(t-1)$-dimensional column vector of zeros with 1 in the $(t-1)$ element. The unknown function $\theta_{F}(z)$ is estimated by solving the first order condition:

$$
\begin{gathered}
0=\sum_{i=1}^{n} \sum_{t=1}^{T_{i}} K_{h}\left(Z_{i t}-z\right) g_{i t}(z, h) \\
L_{i, t \theta}\left(Y_{i}, \hat{\theta}_{F}\left(Z_{i 1}\right), \ldots, \hat{\theta}_{F}(z)+\left\{\left(Z_{i t}-z\right) / h\right\}^{\prime} \frac{\partial \hat{\theta}_{F}(z)}{\partial z}, \ldots, \hat{\theta}_{F}\left(Z_{i T_{i}}\right)\right),
\end{gathered}
$$

where $g_{i t}(z, h)=\left[1,\left\{\left(Z_{i t}-z\right) / h\right\}^{\prime}\right]^{\prime}$ is a column vector of dimension $(q+1)$. Since we use a local linear estimator, which is composed of a constant and a slope for every one of the $q$ variables that enters the model nonparametrically. The argument of $L_{i, t \theta}$ is $\hat{\theta}\left(Z_{i 1}\right)$ for $s \neq t$, and $\hat{\alpha}_{0}(z)+\left\{\left(Z_{i t}-z\right) / h\right\}^{\prime} \hat{\alpha}_{1}(z)$ for $s=t$. This forms the basis for an iterative solution, where, given $\hat{\theta}_{[l-1]}(z)$, the value at step $l-1$, we have step $l$ values $\left(\hat{\theta}_{[l]}(z), \frac{\partial \hat{\theta}_{[l]}(z)}{\partial z}\right)=$ $\left(\hat{\alpha}_{0}, \hat{\alpha}_{1}\right)$, where $\left(\hat{\alpha}_{0}, \hat{\alpha}_{1}\right)$ are the solutions to

$$
\begin{gathered}
0=\sum_{i=1}^{n} \sum_{t=1}^{T_{i}} K_{h}\left(Z_{i t}-z\right) g_{i t}(z, h) \\
L_{i, t \theta}\left(Y_{i}, \hat{\theta}_{[l-1]}(z), \ldots, \hat{\alpha}_{0}(z)+\left\{\left(Z_{i t}-z\right) / h\right\}^{\prime} \hat{\alpha}_{1}(z), \ldots, \hat{\theta}_{[l-1]}\left(Z_{i T_{i}}\right)\right) .
\end{gathered}
$$

Thus, we estimate $\theta_{F}(z)$, the value of the nonparametric function (the local constant), as 
well as its first derivative, $\frac{\partial \theta_{F}(z)}{\partial z}$, with respect to each of the nonparametric variables. The solutions of the kernel estimating equation above are given by $\left(\hat{\alpha}_{0}, \hat{\alpha}_{1}\right)=D_{1}^{-1}\left(D_{2}+D_{3}\right)$, where

$$
\begin{aligned}
D_{1}=\frac{1}{n} & \sum_{i=1}^{n}\left\{e_{T_{i}-1}^{\prime} \Sigma_{i}^{-1} e_{T_{i}-1} K_{h}\left(Z_{i 1}-z\right) g_{i 1} g_{i 1}^{\prime}+\sum_{t=2}^{T_{i}} c_{i, t-1}^{\prime} \Sigma_{i}^{-1} c_{i, t-1} K_{h}\left(Z_{i t}-z\right) g_{i t} g_{i t}^{\prime}\right\} \\
D_{2}=\frac{1}{n} & \sum_{i=1}^{n}\left\{e_{T_{i}-1}^{\prime} \Sigma_{i}^{-1} e_{T_{i}-1} K_{h}\left(Z_{i 1}-z\right) g_{i 1} \hat{\theta}_{[l-1]}\left(z_{i 1}\right)\right. \\
& \left.+\sum_{t=2}^{T_{i}} c_{i, t-1}^{\prime} \Sigma_{i}^{-1} c_{i, t-1} K_{h}\left(Z_{i t}-z\right) g_{i t} \hat{\theta}_{[l-1]}\left(z_{i t}\right)\right\} \\
D_{3}=\frac{1}{n} & \sum_{i=1}^{n}\left\{-K_{h}\left(Z_{i 1}-z\right) g_{i 1} e_{T_{i}-1}^{\prime} \Sigma_{i}^{-1} H_{i,[l-1]}+\sum_{t=2}^{T_{i}} K_{h}\left(Z_{i t}-z\right) g_{i t} c_{i, t-1}^{\prime} \Sigma_{i}^{-1} H_{i,[l-1]}\right\}
\end{aligned}
$$

and where $H_{i,[l-1]}$ is a $\left(T_{i}-1\right)$ column vector with elements $\tilde{Y}_{i t}-\left(\hat{\theta}_{[l-1]}\left(z_{i t}\right)-\hat{\theta}_{[l-1]}\left(z_{i 1}\right)\right)$, for $t=2, \ldots, T_{i}$. The method then consists in iterating until convergence. The variance of the iterative estimate $\hat{\theta}_{F}(z)$ is $\kappa /(n h \hat{\Omega}(z))$, which depends on the second moment of the kernel, $\kappa=\int k^{2}(v) d v$ and on

$$
\hat{\Omega}(z)=\frac{1}{n} \sum_{i=1}^{n} \frac{T_{i}-1}{T_{i}} \sum_{t=2}^{T_{i}} K_{h}\left(Z_{i t}-z\right) / \hat{\sigma}_{v}^{2},
$$

where $\hat{\sigma}_{v}^{2}$ is the estimated variance of the residuals

$$
\hat{\sigma}_{v}^{2}=\frac{1}{2 n} \sum_{i=1}^{n} \frac{1}{T_{i}-1} \sum_{t=2}^{T_{i}}\left(Y_{i t}-Y_{i 1}-\left(\hat{\theta}\left(Z_{i t}\right)-\hat{\theta}\left(Z_{i 1}\right)\right)\right)^{2} .
$$

The semiparametric aspect is handled by a profile-kernel approach, along the lines of Wang, Carroll, and Lin (2005), and the objective function is modified to

$$
L_{i t}=-\frac{1}{2}\left(\tilde{Y}_{i}-\tilde{X}_{i}^{\prime} \beta_{F}-\theta_{i}+\theta_{i 1} e_{T_{i}-1}\right)^{\prime} \Sigma_{i}^{-1}\left(\tilde{Y}_{i}-\tilde{X}_{i}^{\prime} \beta_{F}-\theta_{i}+\theta_{i 1} e_{T_{i}-1}\right),
$$

where $\hat{\theta}_{F}\left(z, \beta_{F}\right)$ replaces $\hat{\theta}_{F}(z)$ in the first order condition, since now everything also depends on the parametric coefficient $\beta_{F}$. It can be shown that $\hat{\theta}_{F}\left(z, \beta_{F}\right)=\hat{\theta}_{y}(z)^{\prime}-\hat{\theta}_{x}(z)^{\prime} \beta_{F}$, 
where $\hat{\theta}_{y}(z)$ is the estimator of the pure nonparametric model (without $X_{i t}$ ), and $\hat{\theta}_{x}(z)=$ $\left(\hat{\theta}_{x, 1}(z), \ldots, \hat{\theta}_{x, d}(z)\right)^{\prime}$, where $\hat{\theta}_{x, r}(z)$ is the nonparametric estimator in the regression of the $r$-th component of $X$ on $Z$. The coefficient of the parametric part $X$, now obtains by GLS of the residuals of $Y$ on the residuals of $X$, as follows:

$$
\hat{\beta}_{F}=\left(\sum_{i=1}^{n} \tilde{X}_{i *}^{\prime} \Sigma_{i}^{-1} \tilde{X}_{i *}\right)^{-1}\left(\sum_{i=1}^{n} \tilde{X}_{i *}^{\prime} \Sigma_{i}^{-1} \tilde{Y}_{i *}\right)
$$

where the residuals of the nonparametric regression of $Y$ on $Z$ are $\tilde{Y}_{i *}=\left(\tilde{Y}_{i 2 *}, \ldots, \tilde{Y}_{i T_{i} *}\right)$, with $\tilde{Y}_{i t *}=\tilde{Y}_{i t}-\left(\hat{\theta}_{y}\left(Z_{i t}\right)-\hat{\theta}_{y}\left(Z_{i 1}\right)\right)$, and the residuals of the nonparametric regression of $X$ on $Z$ are $\tilde{X}_{i *}=\left(\tilde{X}_{i 2 *}, \ldots, \tilde{X}_{i T_{i} *}\right)$, with $\tilde{X}_{i t *}=\tilde{X}_{i t}-\left(\hat{\theta}_{x}\left(Z_{i t}\right)-\hat{\theta}_{x}\left(Z_{i 1}\right)\right)$. 